DOE-EM-0271

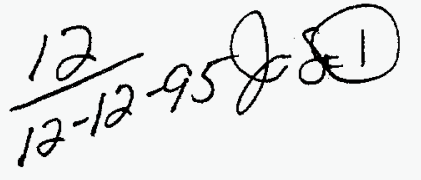

$$
\text { RECTIVED }
$$

BEC 271995
OSTI

Dynamic Underground Stripping

\title{
INNOVATIVE TECHNOLOGY SUMMARY REPORT
}

\section{demonstrated at}

U.S. Department of Energy

Lawrence Livermore National Laboratory

Gasoline Spill Site: GSA

Livermore, CA

\section{prepared for}

U.S. Department of Energy

Office of Environmental Management

Office of Technology Development

April 1995 


\section{DISCLAIMER}

This report was prepared as an account of work sponsored by an agency of the United States Government. Neither the United States Government nor any agency thereof, nor any of their employees, makes any warranty, express or implied, or assumes any legal liability or responsibility for the accuracy, completeness, or usefulness of any information, apparatus, product, or process disclosed, or represents that its use would not infringe privately owned rights. Reference herein to any specific commerical product, process, or service by trade name, trademark, manufacturer, or otherwise does not necessarily constitute or imply its endorsement, recommendations, or favoring by the United States Govemment or any agency thereof. The views and opinions of authors expressed herein do not necessarily state or reflect those of the United States Government or any agency thereof.

This report has been reproduced directly from the best available copy.

Available to DOE and DOE contractors from the Office of Scientific and Technical Information, P.O. Box 62, Oak Ridge, TN 37831; prices available from (615) 576-8401.

Available to the public from the U.S. Department of Commerce, Technology Administration, National Technical Information Service, Springfield, VA 22161.

(703) 487-4650. 


\section{DISCLAMMER}

Portions of this document may be illegible in electronic image products. Images are produced from the best available original document. 


\section{Dynamic Underground Stripping}

\section{INNOVATIVE TECHNOLOGY SUMMARY REPORT}

\section{demonstrated at}

U.S. Department of Energy

Lawrence Livermore National Laboratory

Gasoline Spill Site: GSA

Livermore, CA

\section{prepared for}

\section{U.S. Department of Energy}

Office of Ervironmental Management

Office of Technology Development

\section{April 1995}

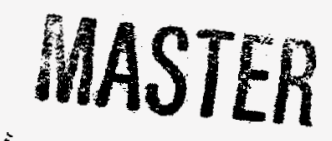

AISTRIBUTION OF THIS DOCUMENT IS UNLIMTEED 


\section{TABLE OF CONTENTS}

\section{APPENDICES}

A Demonstration Site Characteristics

B Technology Description Detail

C Performance Detail

D Commercialization/Intellectual Property

E Cost Detail

F References 


\section{Technology Description}

Dynamic Underground Stripping (DUS) is a combination of several technologies targeted to remediate soil and ground water contaminated with organic compounds. DUS is effective both above and below the water table and is especially well suited for sites with interbedded sand and clay layers. The main technologies which comprise DUS are:

- steam injection at the periphery of a contaminated area to heat permeable subsurface areas, vaporize volatile compounds bound to the soil, and drive contaminants to centrally located vacuum extraction wells;

- electrical heating of less permeable clays and fine-grained sediments to vaporize contaminants and drive them into the steam zone; and

- underground imaging, primarily Electrical Resistance Tomography (ERT), which delineates heated areas to ensure total cleanup and process control.

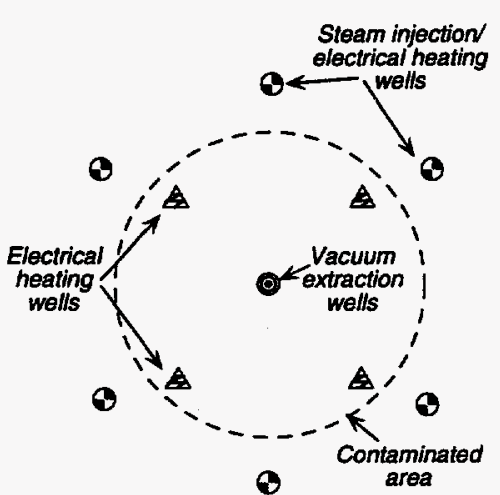

Plan View

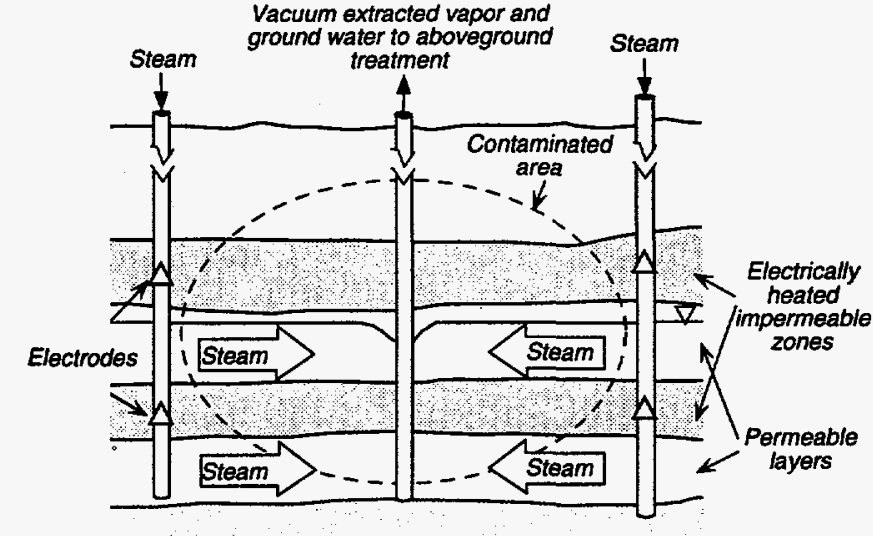

Cross-Sectional View

\section{Technology Status}

A full-scale demonstration was conducted at:

Lawrence Livermore

National Laboratory (LLNL)

Gasoline Spill Site: GSA

Livermore, California

November 1992 through December 1993

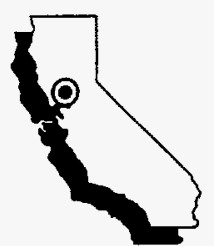

Before application of DUS, the site contained an estimated 6,500 gallons of fuel hydrocarbons (FHCs) both above and below the water table at depths up to $150 \mathrm{ft}$. The site is underlain by complexly interbedded high and low permeability sediments.

\section{Key results included:}

- The system removed over 7,000 gallons of gasoline (more than the original estimate of contamination) during 10 weeks of operation conducted in phases over a 1 -year period. The maximum extraction rate was 250 gallons per day.

- DUS removed the localized underground spill at LLNL more rapidly and cost-effectively than the estimated effectiveness of competing baseline technologies of pump-and-treat or pump-and-treat with vacuum extraction.

- DUS is projected to cost between $\$ 11$ and $\$ 37$ per cu yd of contaminated soil and is projected to remediate a site in six to nine months as opposed to thirty years for the baseline technology of pump and treat. 


\section{Technology Status (continued)}

Over a dozen patents covering the major aspects of DUS are either pending or have already been granted to DOE and the University of California. DUS is licensable from the University of California Office of Technology Transfer, and licensing discussions are currently in progress. The results of the LLNL demonstration illustrating the effectiveness of subsurface heating are corroborated by the results of field-scale demonstrations of other in situ thermal treatment processes conducted through other EPA, DOD, and DOE programs. Conceptual designs, cost estimates, and detailed designs have been prepared for applying DUS at other sites. Future development efforts will focus upon applying the technology at sites contaminated with dense nonaqueous phase liquids (DNAPLs) and at sites with fractured subsurface media.

Contacts

\section{Technical}

Roger Aines, Principal Investigator, LLNL, (510) 423-7184

Robin Newmark, LLNL, (510) 423-3644

Kent Udell, UC Berkeley, (510) 642-2928

\section{Management}

John Mathur, DOE Program Manager, (301) 903-7922

Jim Wright, DOE Plumes Focus Area Implementation Team Manager, (803) 725-7289

\section{Licensing Information}

Kathy Kaufman, Technology Transfer Initiative Program, Lawrence Livermore National Laboratory, (510) $422-2646$

Kathy Willis, University of California Office of Tech Transfer, (510) 748-6595 
SECTION 2

\section{TECHNOLOGY DESCRIPTION}

\section{Overall Process Schematic}

DUS combines steam injection, electrical resistance heating, and underground imaging and monitoring techniques to mobilize and recover contaminants from the subsurface. The figure below is a conceptual illustration of the process for relatively simple subsurface conditions. Appendix B provides detailed information about the process including close-ups of subsurface wells and descriptions of surface treatment equipment.

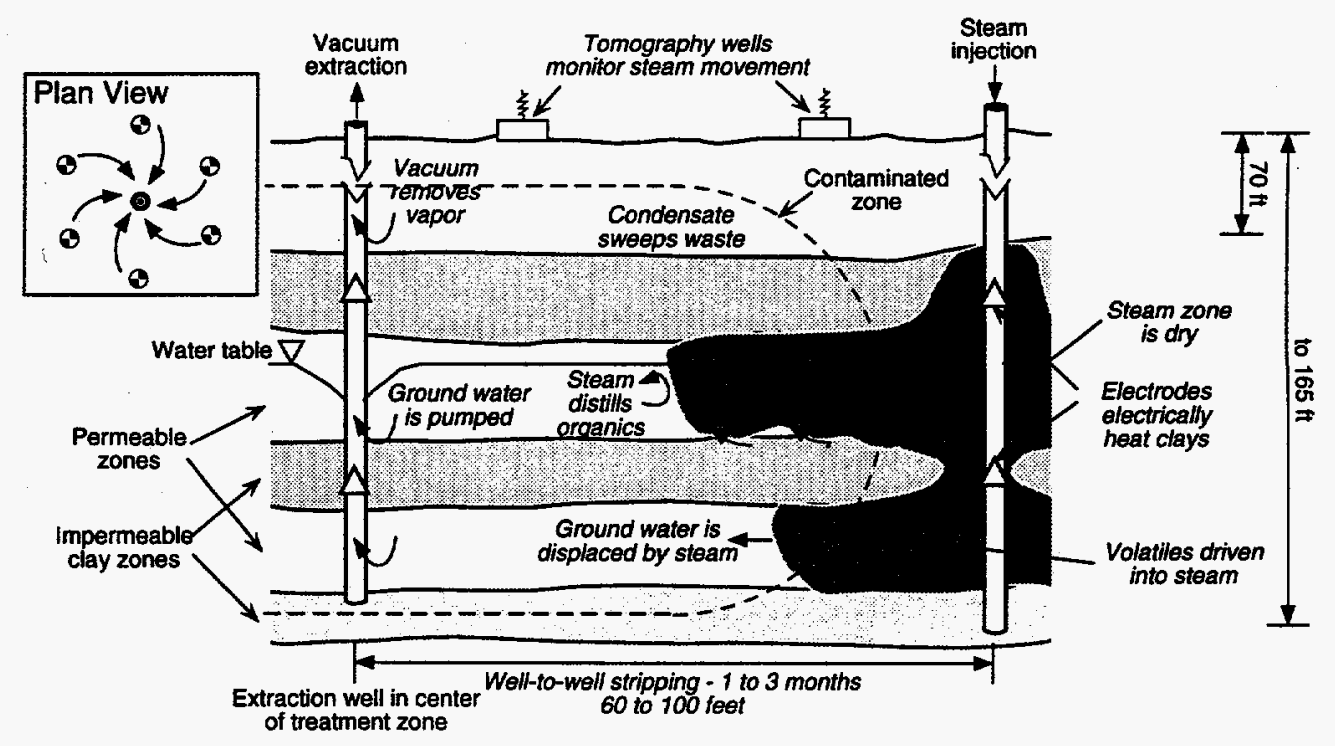

Major elements of the technology are:

Steam Injection and Vacuum Extraction - Injection wells drilled around an area of concentrated contamination supply steam and electric current. Vacuum extraction wells in the center of the contaminated area remove contaminants. A steam front develops in the subsurface as permeable soils are heated to the boiling point of water and volatile organic contaminants are vaporized from the hot soil. The steam moves from the injection to the extraction wells.

Electrical Resistance Heating - Electric current is used to heat impermeable soils. Water and contaminants trapped in these relatively conductive regions are vaporized and forced into the steam zone for vacuum extraction.

Underground Imaging and Monitoring - Several geophysical techniques used to monitor the underground movement of steam and the progress of heating include temperature measurements (taken from monitoring wells throughout the treatment area), ERT (which relates measurement of electrical conductivity to the progress of the steam front in the heated zone, and tiltmeters (which detect small subsurface pressure changes created by the movement of the steam front). 
SECTION 3

\section{PERFORMANCE}

\section{Generalized Treatment Plan}

A generalized approach to implementing DUS developed as a result of the demonstration includes:

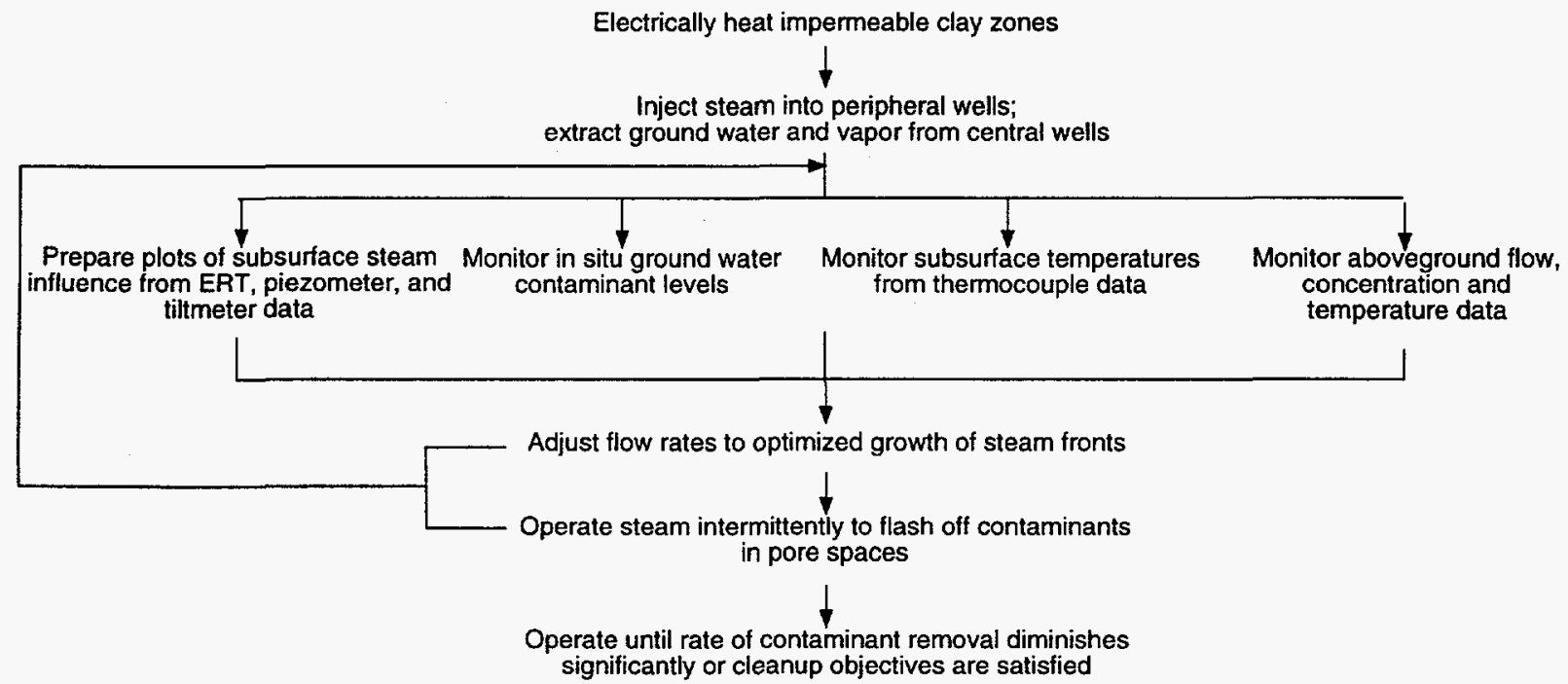

Demonstration Operations and Results Overview

DUS activities at LLNL occurred in a series of demonstration efforts:

\section{PHASE}

Clean Site Demonstration

DUS Demonstration

Electrical Heating Phase

DUS Demonstration

1st Pass Steaming Phase

DUS Demonstration

2nd Pass Steaming Phase

Accelerated Removal \& Validation (ARV) Project

\section{OBJECTIVES/APPROACH}

To field test the DUS process on an uncontaminated site with well-characterized geology

To heat less permeable contaminated clay zones

Continuous steam injection over a 5-week period to vaporize and remove gasoline

Intermittent steam injection and vacuum extraction over a 6-week period Continuous operation to remove residual
contamination; additional electrical heating

Test of process modifications such as altering injection/extraction locations and air sparging

Installation of fiber-optic transmission system to allow for simultaneous electrical heating and process monitoring

\section{KEY RESULTS}

Steam injections, electric heating, and monitoring well design improvements were identified

Identification of improved operating strategy of electric heating before steaming

Temperature of clay layers raised from $70^{\circ} \mathrm{F}$ to $160^{\circ} \mathrm{F}$

Over $1700 \mathrm{gal}$ of gasoline removed

Over 4900 gal of gasoline removed

Temperature of most soils within treatment zone exceeds $212^{\circ} \mathrm{F}$; residual contamination (estimated at $750 \mathrm{gal}$ ) and an unsteamed area ("cold spot") remained

Over $1000 \mathrm{gal}$ of gasoline removed Improved understanding of electrical heating process developed

Sparging tests demonstrated value of modeling and use of tracer gases to better understand subsurface gas flow

Fiber-optics successfully installed 


\section{Treatment Performance}

\section{Reductions in Plume Concentrations}

Estimated Total Fuel Hydrocarbon concentrations before and after the second steam pass of DUS are shown below:
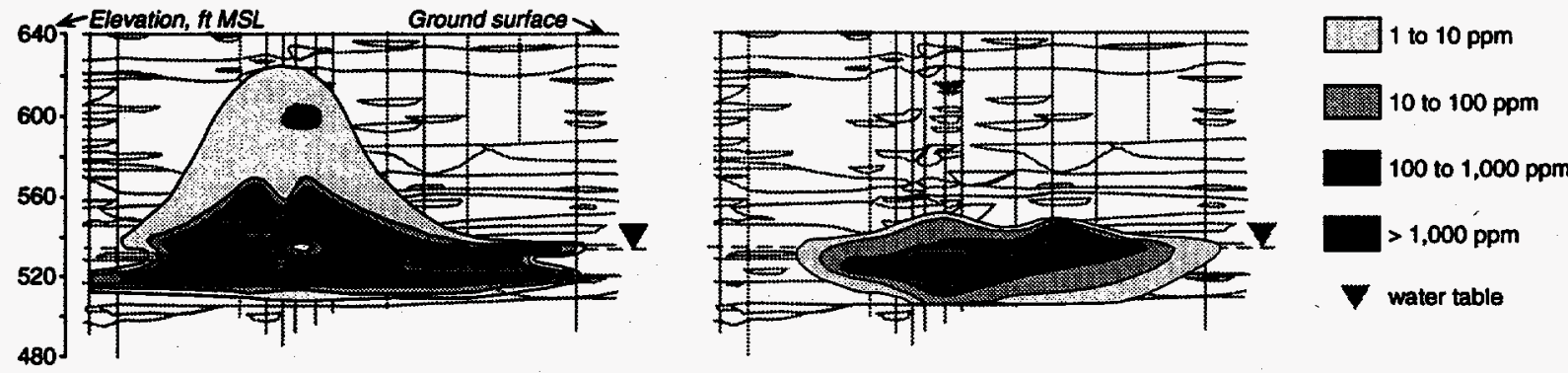

- No spreading observed; contamination drawn to extraction wells.

- Continued operation during the ARV phase removed an additional 1000 gallons.

- The ability of DUS to remove contaminants sorbed to soils was illustrated by a marked rise in benzene and total gasoline concentrations in ground water during DUS. At one ground water monitoring well in the treatment zone, concentrations of $C 6$ to $C 12$ hydrocarbons had been below $30 \mathrm{ppm}$ since 1987, but during DUS these concentrations rose to nearly $150 \mathrm{ppm}$ before dropping to levels below those found before DUS.

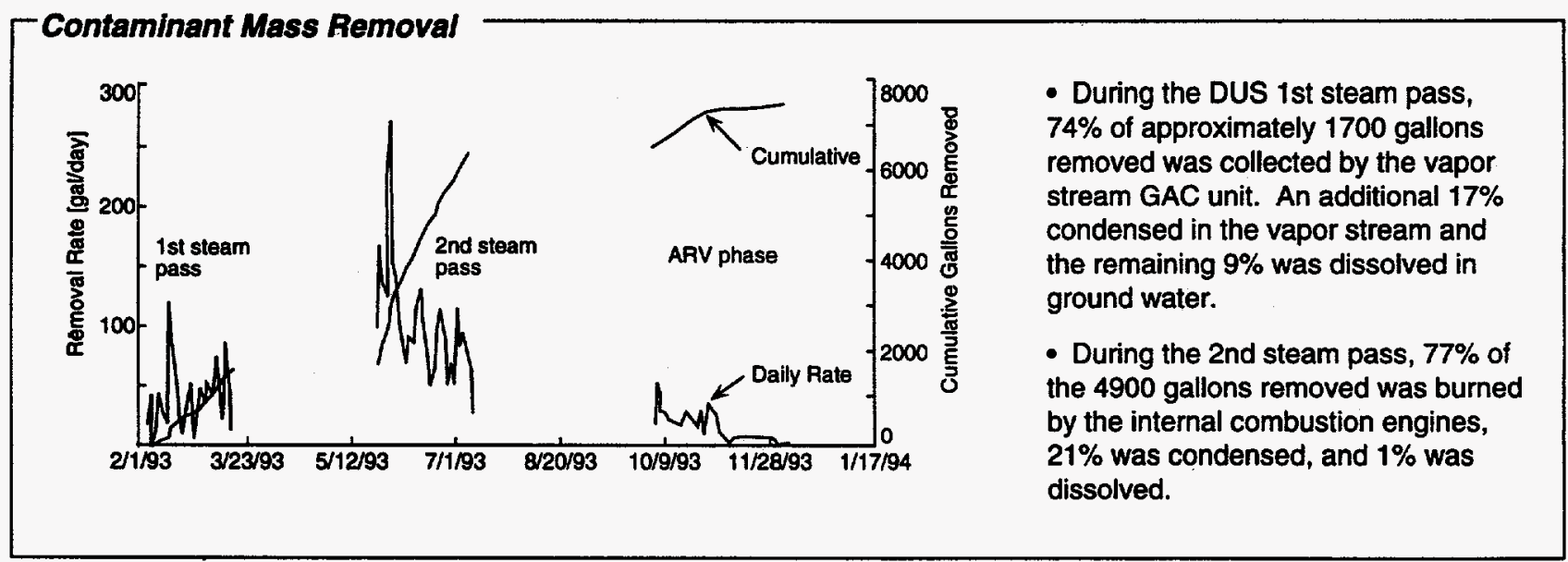

\section{Plume Containment}

- The GSA was an ideal spot for demonstration of DUS because of its low ground water velocities, which kept contamination confined to a relatively small area. The plots at right illustrate that BTEX concentrations in soils at the periphery of the treatment zone declined during the demonstration. This phenomenon was determined to be indicative of the DUS process limiting further migration of contamination.
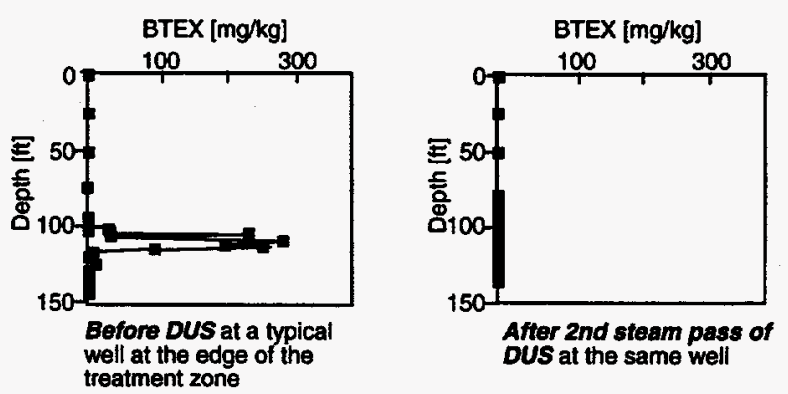


\section{Operational Performance}

\section{Aboveground Treatment Plan Performance}

- The majority of contaminants removed from the subsurface were in the vapor phase.

- Surface treatment consisted of (1) a UV/peroxide unit to treat ground water and condensed vapors during both phases of the demonstration, (2) a GAC unit to treat vapors removed during phase I, and (3) an ICE unit to treat the vapors removed during phase II.

- The volume of contaminated vapors removed from the subsurface was initially underestimated. Thus the GAC unit selected for offgas treatment was undersized. It was replaced by an ICE unit during phase II. The ICE unit could also have been larger but nevertheless performed successfully. Dilution of air was necessary since the hydrocarbon concentrations were above the explosive limit.

- Destruction efficiencies of the UV peroxide liquid treatment unit during the last half of the first steam pass were less than $40 \%$, but adjustments maintained an efficiency over $90 \%$ during the last half of the second steam pass.

- Free gasoline product was found in the UV peroxide unit after the first steam pass.

- $G A C=$ granular activated carbon; ICE = internal combustion engine

\section{In Situ Heating Performance}

- A total of 100,000 yd3 of soil were heated at least to $200^{\circ} \mathrm{F}$ (boiling point at applied vacuum).

- The growth of the hot zone was monitored by ERT and a network of temperature probes and tiltmeters.

- A variety of data was used to prepare multiple representations of heating effects:

\section{Electrical Resistance Tomography Imaging}

Below are images illustrating resistivity change over time between two monitoring wells approximately $50 \mathrm{ft}$ apart in the central part of the treatment zone.

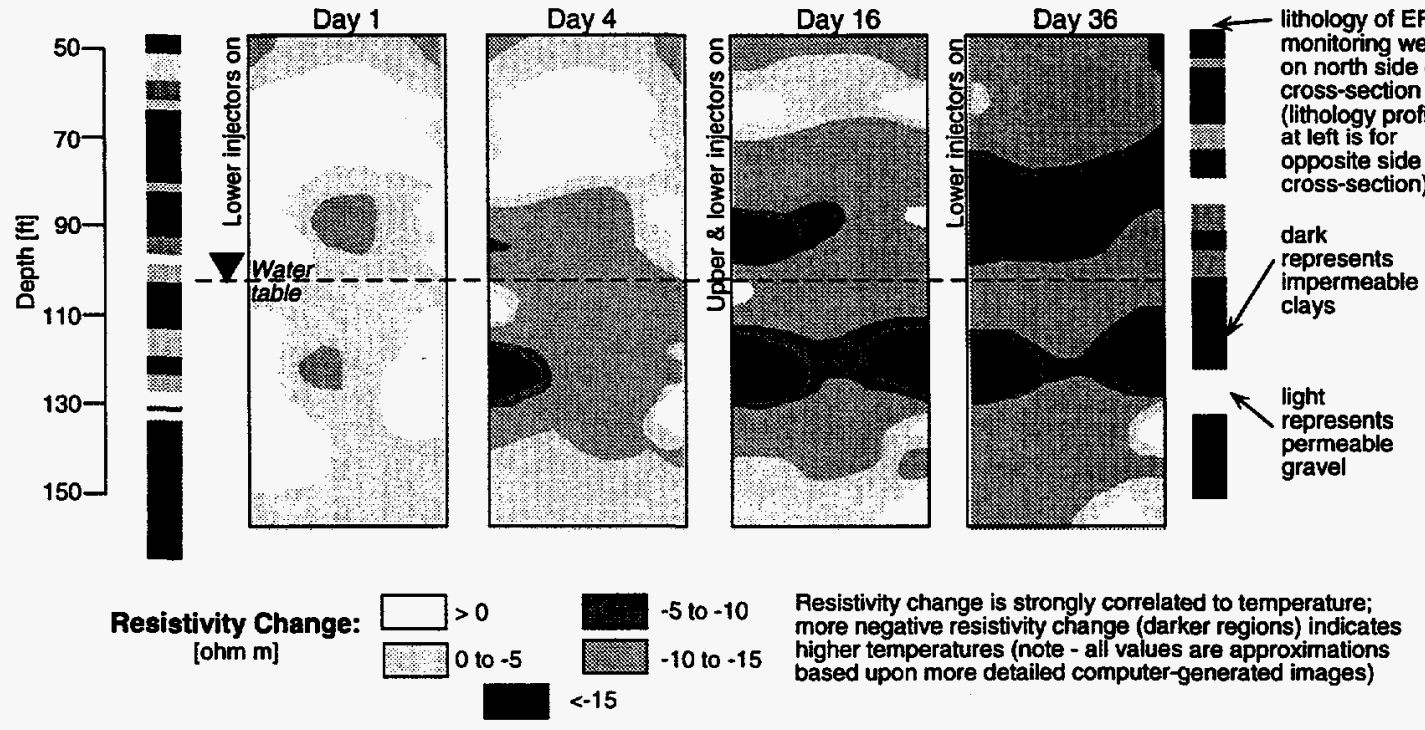

- ERT images provide a continuous representation of steam passage between two electrode-equipped boreholes.

- The process allows identification of "cold spots" and provides data to support efforts to provide uniform heating. 


\section{In Situ Heating Performance (continued)}
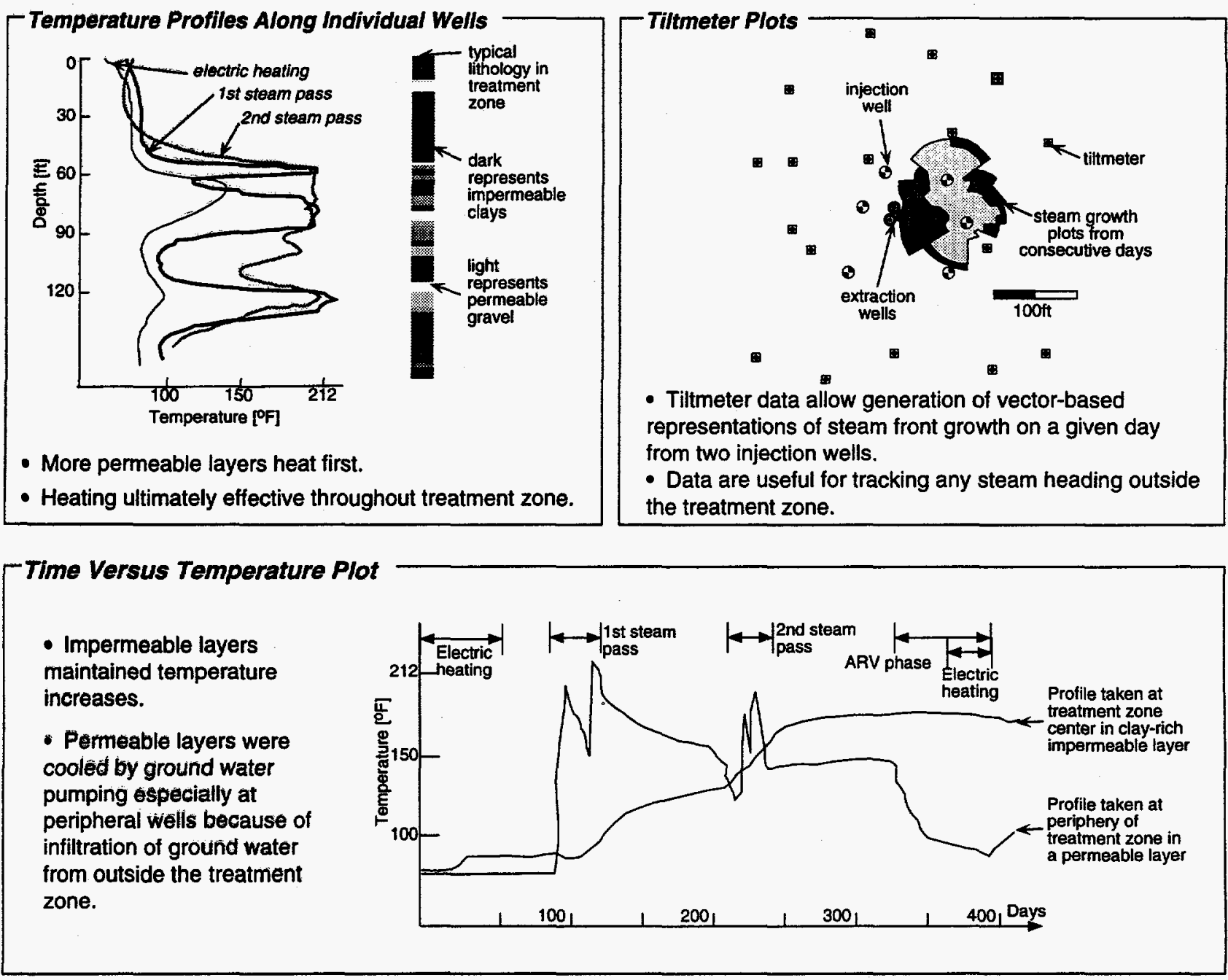


\section{Technology Applicability}

- DUS has been successfully demonstrated to remediate fuel hydrocarbons. Laboratory tests have been successful for a variety of volatile and semivolatile compounds including diesel fuel and both light nonaqeuous phase liquids (LNAPLs) and dense nonaqueous phase liquids (DNAPLs).

- DUS is effective in the presence of free-phase and dissolved-phase contaminant liquids. It is extremely effective in the absence of liquids (vadose zone) but is usually not cost effective versus alternative technologies in these instances. It would be better applied at sites with contamination both above and below the water table.

- The minimum depth for application of DUS is approximately 5 feet. At greater depths, the steam injection pressure can be increased, producing higher efficiencies and extracting more work from each well.

- DUS becomes more cost-effective the larger the application site.

- A key competitive advantage of DUS is the speed of cleanup relative to conventional technologies. This order-ofmagnitude superiority reduces overall cost, reduces risk to nearby populations and the environment, and frees land for beneficial reuse.

- DUS has a potential market at sites where conventional technologies have failed to produce acceptable results. The GSA site at LLNL is an example; soil vapor extraction had been previously applied and its performance predicted a cleanup time of greater than one hundred years.

- DUS is best suited to treat NAPLs and strongly sorbed contaminants in heterogenous or fractured formations. Unlike most competing technologies, it can directly address contamination in complexly interbedded sands and clays. Further information on the applicability of DUS is in Appendix D.

\section{Competing Technologies}

- DUS competes with conventional baseline technologies of pump-and-treat and pump-and-treat combined with soil vapor extraction. LLNL researchers estimated the effectiveness of these technologies at the GSA and compared the estimates with the results of the DUS demonstration, as shown below:

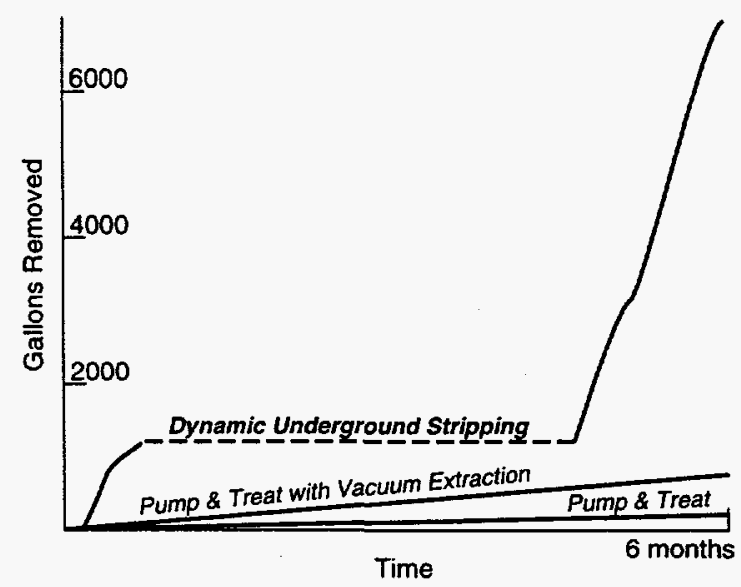

- A variety of in situ thermal treatment technologies have been either demonstrated or developed through DOE, DOD, and EPA programs. The aggregate experience with these programs enhances confidence in the fundamentals of DUS. Full-scale demonstrations of these related technologies include those shown in the table on page 9 . 


\section{Competing Technologies (continued)}

\begin{tabular}{|c|c|c|c|}
\hline 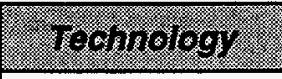 & berrelopes: & 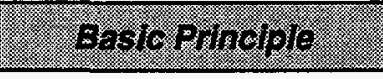 & 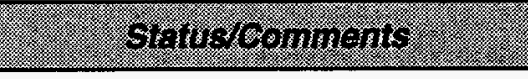 \\
\hline \multicolumn{4}{|l|}{ DOE } \\
\hline $\begin{array}{l}\text { Six-Phase Soil } \\
\text { Heating }\end{array}$ & $\begin{array}{l}\text { Pacific Northwest } \\
\text { Laboratory (PNL) }\end{array}$ & $\begin{array}{l}\text { Combines electrical heating } \\
\text { with soil vapor extraction } \\
\text { (six-phase distributes energy } \\
\text { better) }\end{array}$ & $\begin{array}{l}\text { Full-scale demonstration at DOE } \\
\text { Savannah River as part of the VOC in } \\
\text { Non-Arid Soils and Ground Water } \\
\text { Integrated Demonstration in } 1993 ; \\
\text { partnering/licensing discussions ongoing }\end{array}$ \\
\hline $\begin{array}{l}2 \\
\text { Thermal Enhanced } \\
\text { Vapor Extraction }\end{array}$ & $\begin{array}{l}\text { Sandia National } \\
\text { Laboratories (SNL) }\end{array}$ & $\begin{array}{l}\text { Combines soil vapor } \\
\text { extraction with powerline } \\
\text { frequency (ohmic/electrical) } \\
\text { and radio-frequency soil } \\
\text { heating }\end{array}$ & $\begin{array}{l}\text { Full-scale demonstration planned in } 1994 \\
\text { at SNL chemical waste landtill in part of } \\
\text { the Mixed Waste Landfill Integrated } \\
\text { Demonstration; builds upon previous } \\
\text { demonstrations at Volk Field, WI, Rocky } \\
\text { Mountain Arsenal, CO, and Kelly AFB, TX } \\
\text { (see EPA projects) }\end{array}$ \\
\hline $\begin{array}{l}\text { Radio Frequency } \\
\text { Heating }\end{array}$ & $\begin{array}{l}\text { KAl Technologies, } \\
\text { Inc. }\end{array}$ & $\begin{array}{l}\text { Radio frequency heating of } \\
\text { soils combined with soil } \\
\text { vapor extraction }\end{array}$ & $\begin{array}{l}\text { Field demonstrated on VOC } \\
\text { contaminated soils using a horizontal well } \\
\text { at the DOE Savannah River Site as part } \\
\text { of the VOC in Non-Arid Soils and Ground } \\
\text { Water Integrated Demonstrationin } 1993\end{array}$ \\
\hline \multicolumn{4}{|l|}{ EPADOD } \\
\hline $\begin{array}{l}1 \\
\text { Contained Recovery } \\
\text { of Oily Wastes } \\
\text { (CROW TM) }\end{array}$ & $\begin{array}{l}\text { Western Research } \\
\text { Institute }\end{array}$ & $\begin{array}{l}\text { Steam or hot water } \\
\text { displacement guides } \\
\text { contamination to extraction } \\
\text { wells }\end{array}$ & $\begin{array}{l}\text { EPA SITE field demonstration underway } \\
\text { at the Pennsylvania Power \& Light } \\
\text { Brodhead Creek Superfund site, PA; } \\
\text { pilot-scale demonstrations completed at } \\
\text { a wood treatment site in Minnesota }\end{array}$ \\
\hline $2 \underset{\substack{\text { HRUBOUTR } \\
\text { Process }}}{2}$ & $\begin{array}{l}\text { Hrubetz } \\
\text { Environmental } \\
\text { Services, Inc. }\end{array}$ & $\begin{array}{l}\text { Hot air injection combined } \\
\text { with a surface exhaust } \\
\text { collection system }\end{array}$ & $\begin{array}{l}\text { EPA SITE field demonstration on JP-4 } \\
\text { contaminated soils completed at Kelly } \\
\text { AFB, TX, in } 1993\end{array}$ \\
\hline $\begin{array}{l}\text { In Situ Steam and } \\
\text { Air Stripping }\end{array}$ & $\begin{array}{l}\text { Novaterra, Inc. } \\
\text { (formerty Toxic } \\
\text { Treatments USA, Inc.) }\end{array}$ & $\begin{array}{l}\text { Portable steam and air } \\
\text { injection device (Detoxifier } \mathrm{TM} \text { ) } \\
\text { used in soils }\end{array}$ & $\begin{array}{l}\text { EPA SITE field demonstration conducted } \\
\text { on VOC and SVOC contaminated soils at } \\
\text { the Annex Terminal, San Pedro, CA, in } \\
1989\end{array}$ \\
\hline $4 \begin{array}{c}\text { In Situ Steam } \\
\text { Enhanced } \\
\text { Extraction Process }\end{array}$ & $\begin{array}{l}\text { Praxis Environmental } \\
\text { Technologies, Inc. }\end{array}$ & $\begin{array}{l}\text { Steam injection/vacuum } \\
\text { extraction (same as } 5 \text { and } 7 \text { ) }\end{array}$ & $\begin{array}{l}\text { Field demonstrations underway at Hill } \\
\text { AFB, UT, and McClellan AFB, CA }\end{array}$ \\
\hline $\begin{array}{l}5 \text { In Situ Steam } \\
\text { Enhanced } \\
\text { Extraction Process }\end{array}$ & $\begin{array}{l}\text { Udell Technologies, } \\
\text { Inc. }\end{array}$ & $\begin{array}{l}\text { Steam injection/vacuum } \\
\text { extraction (same as } 4 \text { and } 7 \text { ) }\end{array}$ & $\begin{array}{l}\text { Field demonstrations underway at Naval } \\
\text { Air Stations Lemoore and Alameda in } \\
\text { Califomia; Udell technologies no longer } \\
\text { in existence }\end{array}$ \\
\hline 6 Radio Frequency & $\begin{array}{l}\text { Illinois Institute of } \\
\text { Technology Research } \\
\text { Institute/Haliburton } \\
\text { NUS }\end{array}$ & $\begin{array}{l}\text { Radio frequency heating of } \\
\text { soils combined with soil } \\
\text { vapor extraction }\end{array}$ & $\begin{array}{l}\text { EPA SITE field demonstration completed } \\
\text { at Kelly AFB, TX, in 1993; eartier } \\
\text { demonstrations occurred at Rocky } \\
\text { Mountain Arsenal, CO, and Volk Field, } \\
\text { Wi; demonstration colunded by DOE }\end{array}$ \\
\hline $\begin{array}{l}\text { Steam Enhanced } \\
\text { Recovery System }\end{array}$ & $\begin{array}{l}\text { Hughes Environmental } \\
\text { Systems, Inc. }\end{array}$ & $\begin{array}{l}\text { Steam injection/vacuum } \\
\text { extraction (same as } 4 \text { and } 5 \text { ) }\end{array}$ & $\begin{array}{l}\text { EPA SITE field demonstration completed at } \\
\text { the Rainbow Disposal Site in Huntington } \\
\text { Beach, CA, from } 1991 \text { to } 1993 \text {; Hughes no } \\
\text { longer offering technology }\end{array}$ \\
\hline
\end{tabular}

Further information on these full-scale applications is available in references 16 (DOE programs) and 5 (DOD/EPA programs). In addition EPA's Vendor Information System for Innovative Treatment Technologies (VISITT) electronic database lists additional suppliers of equipment and services related to in situ thermally enhanced recovery of contaminants. These include:

- Bio-Electrics, Inc., Kansas City, MO

- EM\&C Engineering Associates, Costa Mesa, CA

- SIVE Services, Dixon, CA

- Thermatrix, Inc., San Jose, CA 


\section{SECTION 5 Cost}

\section{Cost Estimate for Future Applications}

LLNL researchers have developed projected costs for applying DUS to other sites based upon demonstration results (actual costs for demonstration at LLNL are presented in Appendix E). An estimate was prepared for remediating a shallow (less than $\mathbf{5 0} \mathrm{ft}$ in depth) chlorinated solvent spill. The proposed implementation approach involved successive application of DUS to $10,000 \mathrm{yd}^{3}$ cells by relocating equipment to various locations at the site. Key results of the cost estimate were as follows:

- Cleanup of the entire site (an estimated volume of 20,000 to $40,000 \mathrm{yd}^{3}$ ) would cost approximately $\$ 28 / \mathrm{yd}^{3}$.

- A pilot treatability study using full-scale equipment would cost $\$ 37 / y d^{3}$. Economics improve as the area to be remediated increases; LLNL researchers believe that larger sites could be engineered to cost $\$ 11-15 / \mathrm{yd}^{3}$.

- The total cost for DUS implementation was estimated to be less than the first-year cost of constructing and operating a conventional groundwater pump-and-treat facility.

- Remediation costs are highly dependent upon estimated length of time for cleanup. A cost analysis study completed by LANL predicts a cost of $\$ 64 / \mathrm{yd}^{3}$ if the cleanup of $29,000 \mathrm{cu}$. yds. of soil takes two years; if the cleanup can be performed in six months, the cost is $\$ 16 / \mathrm{cu}^{\mathrm{y}} \mathrm{d}^{3}$.

The following table details the equipment and labor costs associated with the treatability demonstration, full-scale operation for the first two $10,000 \mathrm{yd}^{3}$ treatment cells, and subsequent pairs of $10,000 \mathrm{yd}^{3}$ treatment cells.

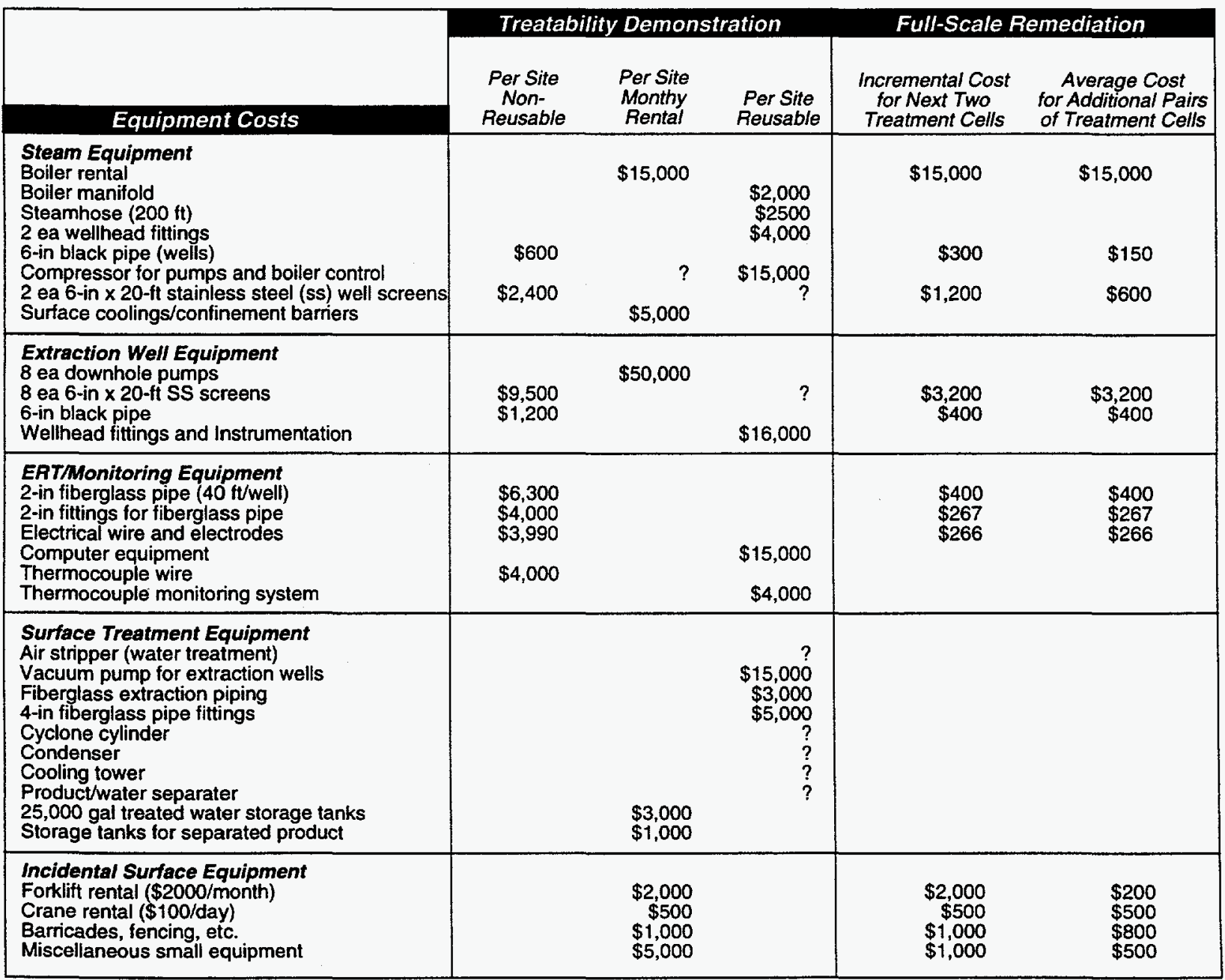




\section{Cost Estimate for Future Applications (continued)}

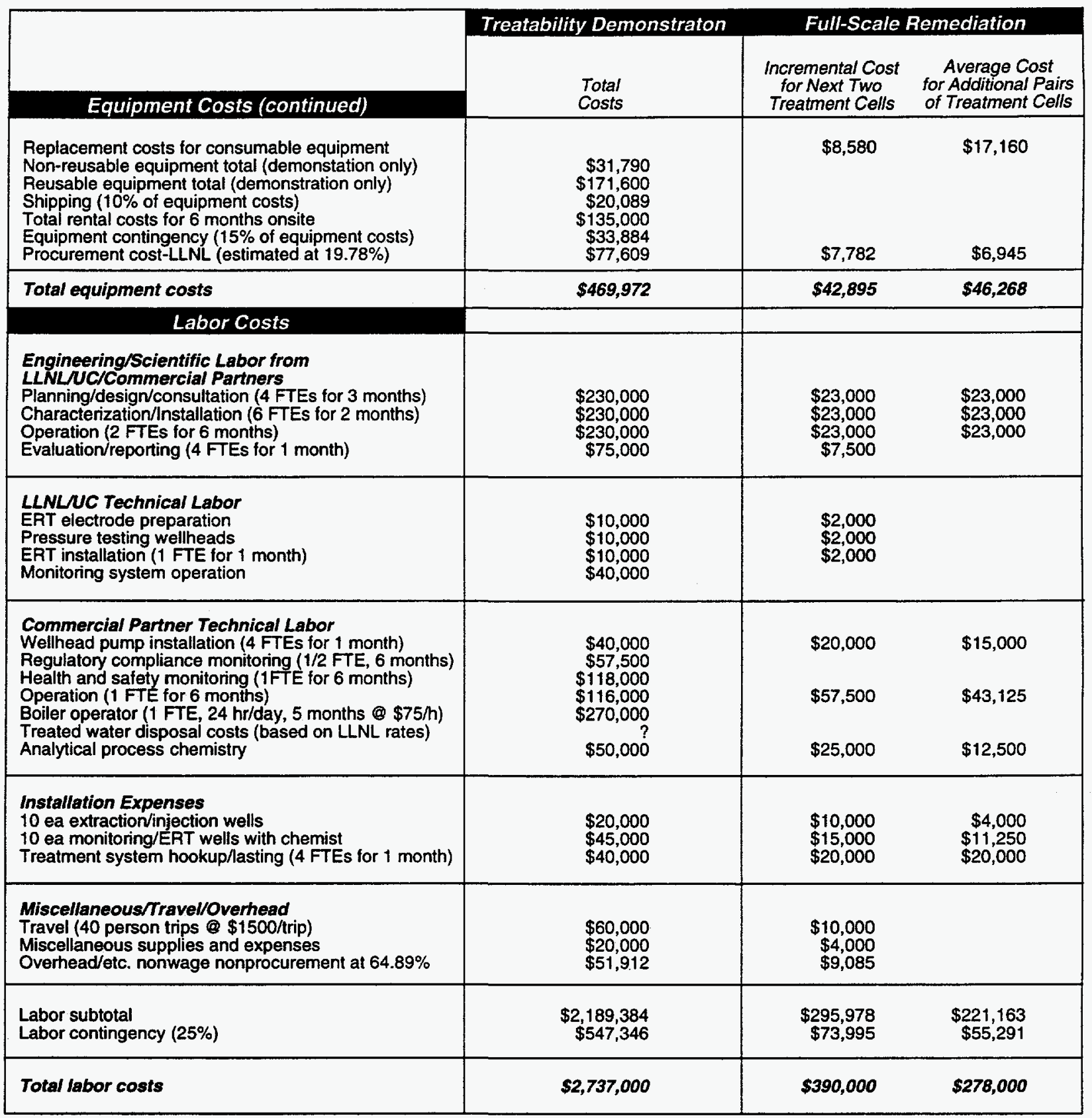

NOTE: All costs are preliminary approximations for work within the DOE environment (overhead, travel, and procurement charges may be less for other applications). Costs not specified in this estimate include costs for disposal of boiler blowdown (if any) and equipment for offgas treatment (see Appendix $E$ for vapor phase equipment costs during demonstration). 


\section{Cost Savings Versus Alternative Technologies}

LLNL researchers compared DUS costs and remediation times with estimated costs and cleanup times of applying alternative technologies at the GSA:
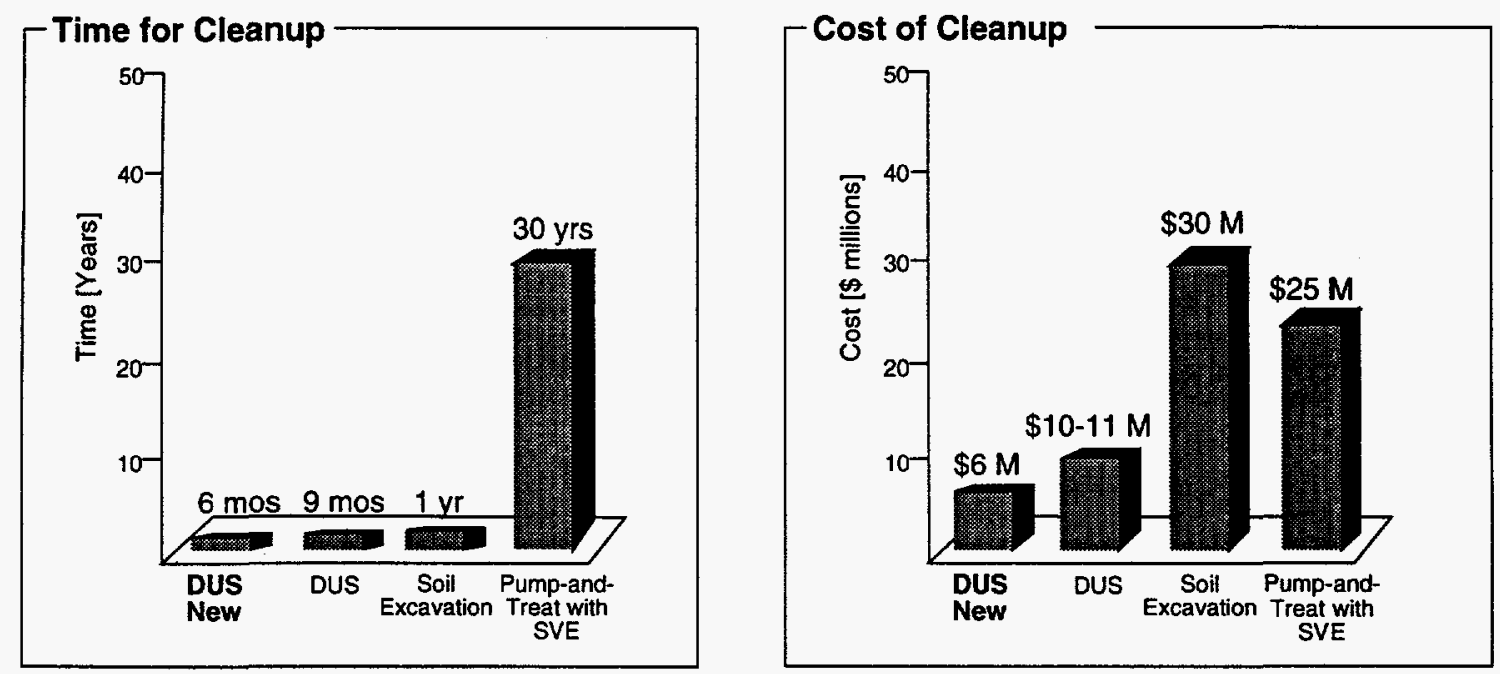

Notes: DUS New = cost of commercial application of DUS at the GSA; assumes $40 \%$ reduction from demonstration costs due to use of lessons learned and elimination of research-oriented activities; detailed in Appendix $E$

DUS = cost of demonstration program for DUS

Soil Excavation includes relocation of underground utilities

SVE $=$ soil vapor extraction 


\section{REGULATORY/POLICY REQUIREMENTS \& ISSUES}

\section{Regulatory Considerations}

Permit requirements for future applications of DUS are expected to include:

- air permits for operation of steam generation equipment and discharge from surface treatment equipment (i.e., air stripper, GAC units, or internal combustion engine)

- liquid effluent discharge permits from aboveground treatment systems (discharge criteria are likely to be related to ground water cleanup levels)

For applications in some states, underground injection permits may be required for system application.

Permitting requirements and regulatory considerations arising from the demonstration at LLNL and relevant to future applications elsewhere are detailed below.

\section{Water}

- Ground wáter cleanup levels have been established for the major contaminants at the GSA:

\begin{tabular}{lccc} 
COMPOUND & FEDERAL & CALIFORNIA & NPDES \\
& $M C L$ (ppb) & $M C L(p p b)$ & LMIT (ppb) \\
\hline Benzene & 5 & 1 & 0.7 \\
Toluene & 1,000 & - & 5 \\
Ethyl benzene & 700 & 680 & 5 \\
Xylenes (total) & 10,000 & 1,750 & 5 \\
Total VOCs & - & - & 5 \\
NOTE: MCL = Maximum Contaminant Level; NPDES = National Pollutant Discharge Elimination System
\end{tabular}

- Remediation will continue until in situ soil concentrations are deemed not to adversely impact groundwater. Those levels are determined through monitoring and modeling efforts as well by using the criteria listed above.

\section{Air}

- The timetable for the DUS demonstration was dictated by the air permits issued for the project. The system was shut down while it was still removing $\mathbf{5 0}$ gal/day of gasoline, and an unheated region remained because the air discharge allowances had been consumed.

- The boiler for steam generation utilized Best Available Control Technology (BACT) consisting of a low NOx burner design and flue gas recirculation to control NOx emission to $40 \mathrm{ppm}$. The Bay Area Air Quality Management District (BAAQMD) granted a research exemption for the project instead of requiring LLNL to purchase an emission allotment of $2,200 \mathrm{lbs}(1.6 \mathrm{lbs} / \mathrm{hr})$ of NOx.

- The BAAQMD issued permits for the following:

\begin{tabular}{lccc} 
& & SAMPLING & DISCHARGE \\
DISCHARGE & COMPOUND & FREQUENCY & LIMIT \\
\hline Air stripper & Total hydrocarbons & $5 / w k$ & $10 \mathrm{ppm}$ \\
GAC & Total hydrocarbons & $5 / \mathrm{wk}$ & $10 \mathrm{ppm}$ \\
IC engine & Total hydrocarbons & $5 / w k$ & Destruction $>98.5 \%$ \\
Sitewide benzene & Benzene & Monthly & $1.815 \mathrm{lbs} /$ day
\end{tabular}

- The LLNL DUS demonstration project incurred one violation from the BAAQMD because of higher than anticipated concentrations of VOCs in extracted vapor streams exceeding the capacity of surface treatment systems. 


\section{Regulatory Considerations (continued)}

\section{Other Considerations}

- Waste forms generated by DUS include the air and liquid discharges (effluent limitations listed above) as well as spent activated carbon. The carbon can be either regenerated or landfilled and poses no unusual regulatory or permitting burden.

- As dictated in the LLNL sitewide Record of Decision and Remedial Implementation Plan, project milestones for site cleanup specify dates for designing and starting various treatment facilities to satisfy overall objectives of protecting human health and the environment in the shortest time possible. DUS represents the most rapid alternative identified during feasibility studies for achieving these objectives.

- No anticipated regulatory developments are expected to change the ability of DUS to comply with relevant requirements. Use of the technology at sites other than LLNL is not expected to be conducted under more stringent requirements. In some cases, permitting of airbome discharges may be easier.

\section{Safety, Risks, Benefits, and Community Reaction}

\section{Worker Safety}

- Operational Safety Procedures were developed to address DUS-specific safety issues not covered by existing LLNL procedures. Areas of concern included hazards posed by the steam generating equipment, electrical hazards from the large currents utilized, proper handling of pressurized steam injection wells, and hazards posed by implementation of ERT.

- Although large amounts of contaminants are more quickly extracted from the ground with DUS than with conventional technologies, safety measures for handling extracted liquid and vapor streams are similar to those for the conventional technologies. One exception, however, is that in some instances the contaminant concentrations of extracted vapors exceeded the upper explosive limits for the mixture.

- Level D personnel protection was used during installation and operation of DUS.

\section{Community Safety}

- Although DUS involves handling extracted vapor and liquid streams with higher concentrations of contaminants than conventional technologies, the dramatically increased speed of cleanup reduces long-term risks to nearby populations.

- DUS employs real-time monitoring controls, which greatly reduces the likelihood of accidents or offsite migration of contaminants.

\section{Environmental Impacts}

- DUS speeds cleanup relative to conventional technologies freeing land for beneficial reuse. Contaminants are either destroyed or are concentrated, transferred to other media, and disposed of offsite depending upon the configuration of surface treatment equipment.

\section{Socioeconomic Impacts and Community Perception}

- Unlike some other long-term remedial alternatives, DUS will require a staff only for a limited period of time. Selection of DUS can reduce the amount of time an environmental restoration work force is needed at some installations.

- DUS has received positive support from the general public at the LLNL Community Work Group Meetings. The basic principles of the technology have been readily understood by both technical and nontechnical audiences. 


\section{Design Issues}

- The DUS demonstration made use of an existing groundwater treatment facility designed to treat gasoline and low levels of chlorinated solvents for the design life of 30 years. The facility utilized oil/water separation, $U V / H_{2} \mathrm{O}_{2}$, and $\mathrm{GAC}$ for the liquid phase and GAC for the vapor phase. This design was not optimal for DUS conditions. The large vapor flows loaded with fuel hydrocarbons required installation of an internal combustion engine to replace the GAC. The high temperature process created conditions unfavorable to UV treatment (increased carbonates and silicates in the extracted liquids would come out of solution when cooled in the UV unit). Packed tower air stripping may be more appropriate for similar applications in the future.

- The success of the DUS process is dependent upon boiling the subsurface environment. The process must be designed not only to bring soil and groundwater to steam temperature but to impart a large amount of energy to create a complete steam zone. Sufficient steam must be injected to counter the cooling effects of inflow of ground water into the treatment zone.

- Aboveground treatment systems must be sized to handle anticipated peak extraction rates and the expected distribution of VOCs in extracted vapor and liquid streams. During demonstration, the majority of extracted VOCs were in the vapor stream. Initially, the vapor treatment system was undersized to handle this stream.

- Aboveground treatment systems must be located so as not to interfere with access to the subsurface treatment zone. This is necessary to avoid situations in which additional injection, extraction, heating, or monitoring wells need to be installed in a spot occupied by surface equipment.

\section{Implementation Considerations}

- Effective removal of contaminants from the subsurface requires repeated creation of the steam zone by successive phases of steam injection and continuous vacuum extraction. The pressure changes created by this oscillatory approach distill contaminants from pore spaces in both saturated and unsaturated sediments.

- Operational difficulties encountered included biofouling from microorganisms destroyed by steaming, scaling and deposits on sensors, and clogging from fines brought to the surface. Maintenance plans must address these situations in future applications by scheduling for routine cleaning of equipment.

- Extraction rates can vary greatly depending upon the amount of steam injected, the total vacuum applied, and cycle times.

- Permitting of air discharges from both aboveground treatment units and equipment used to supply steam energy is an issue requiring early attention.

- DUS is a labor intensive process requiring significant field expertise to implement.

- ERT proved to be the most effective method for monitoring the DUS process in real time. Alternative geophysical techniques could be used for other applications.

\section{Technology Limitations/Needs for Future Development}

- Data on long-term routine operating experience with DUS are not yet available but are needed to better plan future applications.

- Treated soils can remain at elevated temperatures for months and even years after cleanup. This could impact site reuse plans. Soil venting can greatly accelerate the cooling process.

- Future development needs currently identified for DUS include: 1) demonstrating the process for removing chlorinated solvents including DNAPLs, mixed wastes, and sites with fractured subsurface media; 2)automating monitoring techniques; and 3 ) further refining system design and operating techniques. 


\section{Technology Limitations/Needs for Future Development (continued)}

- DUS is effective in the presence of free-phase and dissolved-phase contaminant liquids. It is extremely effective in the absence of liquids (vadose zone) but is usually not cost effective versus alternative technologies in these instances.

- DUS is not applicable at depths less than five feet. At greater depths, the steam injection pressure can be increased, which produces higher efficiencies and extracts more work from each well. (More information on technology applicability is located in Section 4 and Appendix D.)

\section{Future Technology Selection Considerations}

- DUS was effective at quickly removing concentrated free-product contaminants, including materials sorbed to saturated sediments, without mobilizing contaminants outside the treatment zone.

- Steam injection is effective at heating permeable zones, and repeated steam passes, when combined with electric heating, can heat adjacent impermeable areas.

- Electrical heating is effective on clay zones; however, power requirements increase when extracting hot fluids from the treatment zone.

- Future applications of DUS will be designed to focus on mobile/temporary aboveground treatment and steam injection systems that can treat plumes on a cell by cell basis.

- DUS is compatible with long-term efforts to bioremediate residual contamination following steam injection. After application of DUS at LLNL, viable microbial populations continued to degrade gasoline at the site at temperatures above ${ }^{158^{\circ}} \mathrm{F}$. Although microbial populations present after application of DUS were different from those present before treatment, the treatment zone was not sterilized.

- DUS can compare favorably in terms of speed, effectiveness and cost with alternative technologies for deep subsurface plumes. At LLNL, significant cost savings were realized from DUS as opposed to installation of soil vapor extraction/pump-and-treat systems or excavation of contaminated areas. Further reductions in DUS cost are anticipated as experience is gained that will optimize subsequent applications. 


\section{DEMONSTRATION SITE CHARACTERISTICS}

\section{Site History/Background}

- The 800-acre LLNL site was converted from agricultural use into a flight training base and aircraft assembly and repair facility by the Navy in 1942. In 1951, the Atomic Energy Commission converted the site into a weapons design and basic physics research laboratory. Later site missions have included programs in biomedicine, energy, lasers, magnetic fusion energy, and environmental science.

- Initial releases of hazardous materials occurred in the mid to late 1940 s. There is also evidence that subsequent localized spills, leaking tanks and impoundments, process cooling water, and landfills released VOCs, FHCs, lead, chromium, and tritium to sediments and groundwater primarily from 14 major source areas of contamination.

- Between 1952 and 1979, based upon inventory records, as much as 17,000 gallons of leaded gasoline was released from underground storage tanks (USTs) beneath a gasoline filling station in an area now designated the GSA. The GSA occupies an approximately 1.25-acre level area at the southern edge of LLNL and is the site of the DUS application.

- Land north and south of the site is zoned for industrial use, high-density urban areas are west of the site, and the east side is primarily agricultural. Immediately south of the GSA are facilities owned and operated by Sandia National Laboratories. The climate is semiarid with annual precipitation of around 14 inches/year.

- Corrective actions taken since 1988 at the GSA have included the removal and sand filling of four USTs, installation of a gas skimmer which removed 100-150 gal of gasoline, soil vapor extraction of about 1900 gal, and intermittent use of a groundwater pump-and-treat system using $\mathrm{UV} / \mathrm{H}_{2} \mathrm{O}_{2}$ treatment. A large subsurface microbiological population indicates that indigenous microbes have metabolized additional gasoline constituents

\section{Contaminants of Concern}

Contaminants of concern focused on during the remediation are:

- benzene.

- toluene,

- ethylbenzene,

- xylene (mixture of m-, 0-, and p-xylenes), and

-1,2-dichloroethane.

Low levels of other chlorinated solvents are also present in the GSA but were not specifically targeted by DUS remediation efforts.

\begin{tabular}{|c|c|c|c|c|c|}
\hline Property at STP* & Units & $\mathbf{B}$ & $T$ & $E$ & $\bar{x}$ \\
\hline Empirical Formula & - & $\mathrm{C}_{6} \mathrm{H}_{6}$ & $\mathrm{C}_{6} \mathrm{H}_{5} \mathrm{C}_{2} \mathrm{H}_{5}$ & $\mathrm{C}_{6} \mathrm{H}_{5} \mathrm{CH}_{3}$ & $\mathrm{C}_{6} \mathrm{H}_{4}\left(\mathrm{CH}_{3}\right)_{2 \mathrm{~m}}$ \\
\hline Density & $\mathrm{g} / \mathrm{cm}^{3}$ & 0.87 & 0.87 & 0.87 & -0.87 \\
\hline Vapor Pressure & $\mathrm{mmHg}$ & 75 & 29 & 7 & 10 \\
\hline Water Solubility & $\mathrm{mg} / \mathrm{L}$ & 1,780 & 534 & 161 & 178 \\
\hline $\begin{array}{l}\text { Octanol-Water } \\
\text { Partifio- Wation } \\
\text { Coefticient; } \mathrm{K}_{\mathrm{ow}}\end{array}$ & - & 132 & 490 & 1,413 & 1,830 \\
\hline $\begin{array}{l}\text { Organic Carbon } \\
\text { Partition } \\
\text { Coefficient; } \mathrm{K}_{\mathrm{oc}}\end{array}$ & - & 50 & 339 & 565 & 255 \\
\hline
\end{tabular}

\section{Nature and Extent of Contamination}

- The volume of FHC as gasoline before any remediation efforts was estimated based on soil and ground water sampling to be approximately $16,000-17,000$ gal: 6,000 in the vadose zone, 10,000-11,000 in saturated sediments, and 100 dissolved in ground water. Mass volume estimates made immediately before application of DUS identified approximately $6,500 \mathrm{gal}$ of gasoline within the treatment zone.

- High concentrations of gasoline in saturated sediments indicated the likelihood of free phase gasoline. The free phase was trapped within low-permeability sediments below a ground water table that has risen 10 to $30 \mathrm{ft}$ since the time of the main portion of the release (1979) because of the cessation of agricultural pumping.

- FHC concentrations exceed $10 \mathrm{ppm}$ only in the immediate vicinity of the release point with concentrations decreasing to $1 \mathrm{ppm}$ and $100 \mathrm{ppb}$ at 35-40 ft and 40-45 ft, respectively. Benzene levels above $1 \mathrm{ppb}$ (California $\mathrm{MCL}$ is now $0.5 \mathrm{ppb}$ ) are found within $300 \mathrm{ft}$. FHCs were not found below a depth of $150 \mathrm{ft}$. 


\section{Contaminant Locations and Hydrogeologic Profiles}

The GSA has been extensively studied since 1984. Over 70 subsurface borings and monitoring wells revealing the area's geologic, physical, and chemical characteristics have been completed. Short- and longterm drawdown, injection, and extraction tests were conducted to assess hydraulic properties. Pneumatic data derived from soil vapor extraction efforts have also been collected.

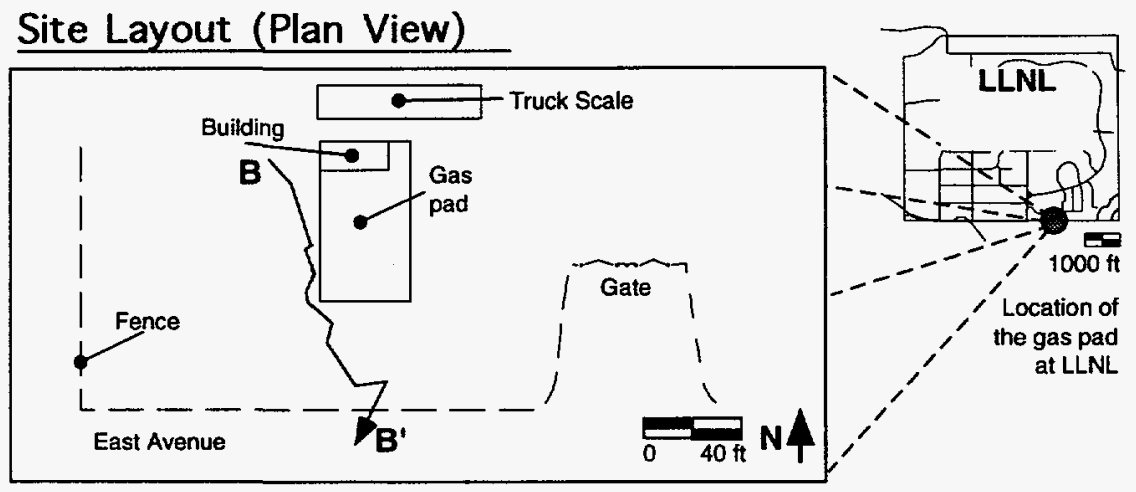

\section{Cross-Sectional View}

Four hydrogeologic units and seven hydrostratigraphic layers have been identified along cross-section B-B' shown in the plan view above. An FHC concentration profile along this cross-section is provided in Section 3.

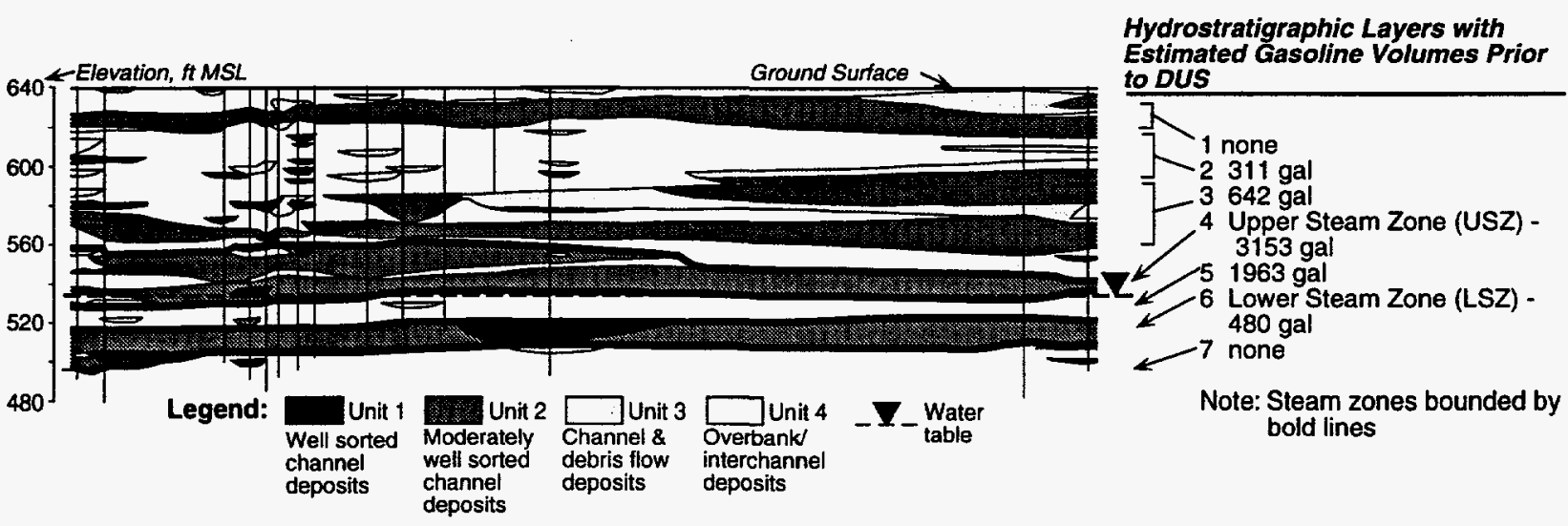

\section{Hydrogeologic Unit Characterization}

\begin{tabular}{lll}
\hline Hydraulic & $\begin{array}{l}\text { Conductivity } \\
\text { Range [gpd/ft2] }\end{array}$ & $\begin{array}{l}\text { Interpreted } \\
\text { Permeability }\end{array}$ \\
\hline 1 & 15 to 1070 & $\begin{array}{l}\text { Very high to high } \\
\text { (mean=280) } \\
\text { High to moderate } \\
\text { (mean=154) }\end{array}$ \\
$2 \quad 13$ to 1000 & $\begin{array}{l}\text { Moderate to low } \\
\text { (mean=116) } \\
\text { Low }\end{array}$ \\
4 & 16 to 170 & $\begin{array}{l}\text { Low to } 18 \\
\text { (mean=11) }\end{array}$
\end{tabular}

\section{Hydrostratigraphic Layer Characterization}

1 5-15-ft-thick interval of coarse-grained high-permeability sandy gravels and gravelly sands

230 -ft-thick, laterally continuous interval of clayey silts to silty clays

3 very heterogeneous zone of elongated lenses of channel sands and gravels interbedded with intervals of silty clays and clayey silts from 50 to $80 \mathrm{ft}$ depth; forms aquitard over USZ

4 partially saturated water-bearing zone composed of a heterogenous mix of high to low permeability sandy to clayey gravels and gravelly to silty sands, 80 to $100 \mathrm{ft}$ depth

5 low-permeability silty clays and clayey silts; forms barrier between the USZ and LSZ 6 high-permeability laterally continuous gravelly sands and sandy gravels; average thickness of $11 \mathrm{ft}$

7 laterally continuous sequence of silty clays to clayey silts at least $15 \mathrm{ft}$ below base of LSZ

NOTE: The two steam zones appear to be hydraulically isolated from adjacent aquilers, are relatively permeable, and contain the most elevated FHC concentrations.

- The site is underlain by several hundred feet of complexly interbedded alluvial and lacustrine sediments.

- Depth to ground water in the GSA is approximately 100 to $120 \mathrm{ft}$

- Regional ground water flow is generally westward, locally stratified, and primarily horizontal.

- Pumping tests and the distribution of contaminants at LLNL indicate a high degree of horizontal subsurface communication. Minimal observed communication in the vertical direction and the layered alluvium restricts downward migration of contaminants. 


\section{Contaminant Locations and Hydrogeologic Profiles (continued)}

Areal Extent of Benzene Contamination_ (before application of DUS)

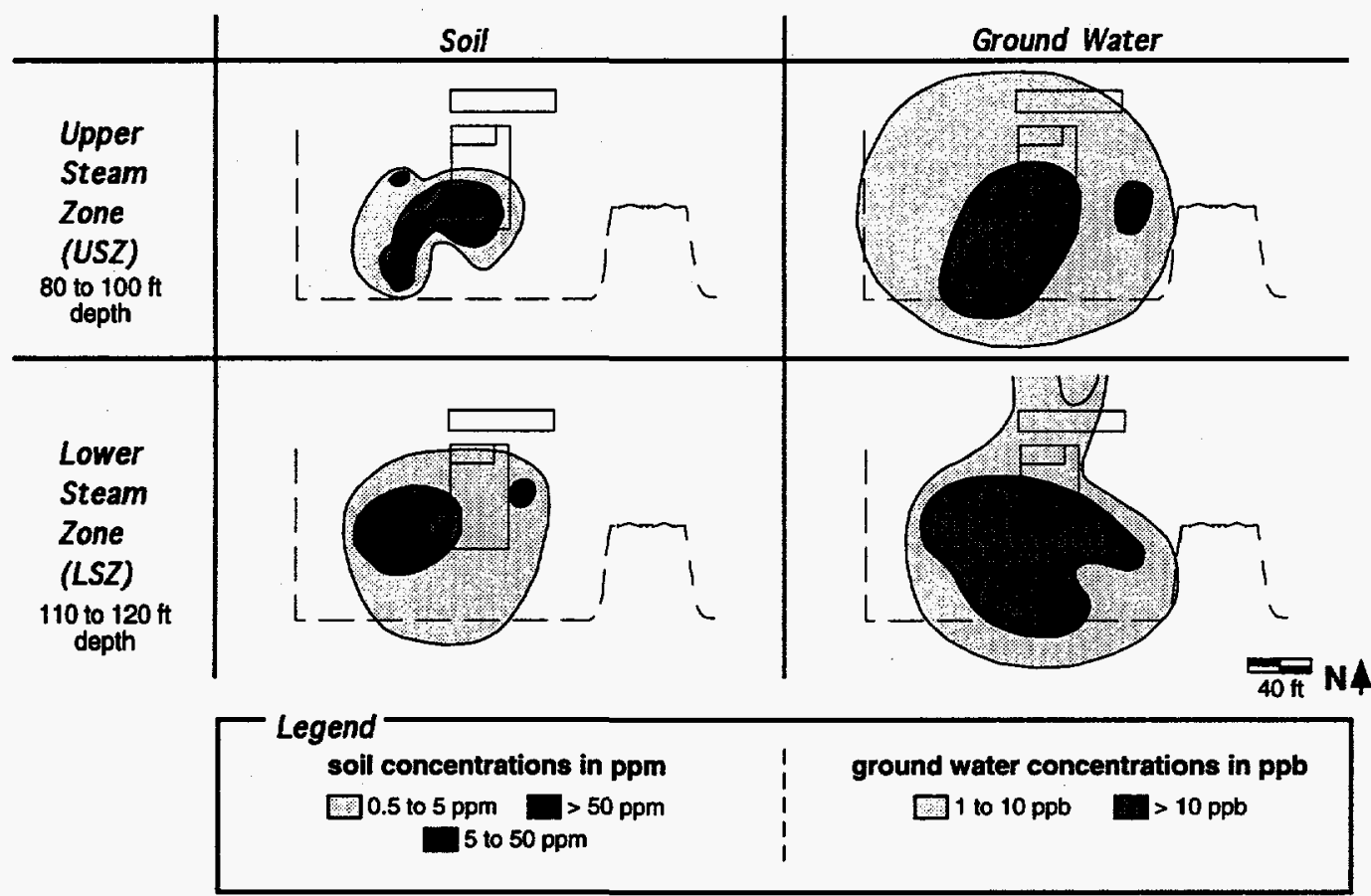


APPENDIX B

TECHNOLOGY DESCRIPTION DETAIL

\section{System Configuration}

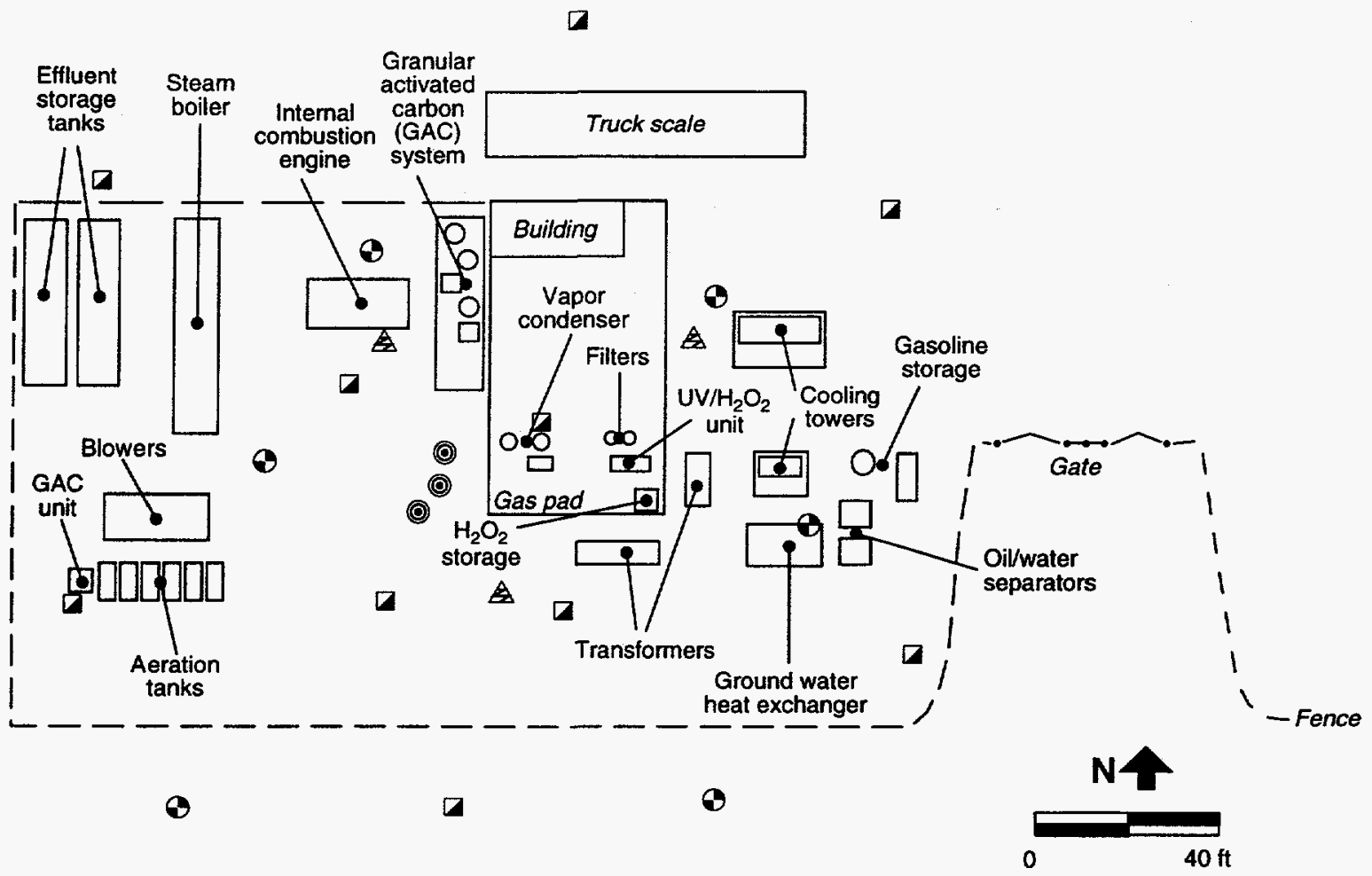

NOTE: 21 tiltmeters (not shown) were also utilized. Additional subsurface borings and ground water monitoring wells are present from initial and ongoing characterization activities.

\section{Legend \\ (O) Extraction \\ Injection \\ Well \\ Geophysical \\ Monitoring Well \\ ERT, thermocouple
and piezometer)}

\section{Operational Requirements}

- Typical staffing requirements for future applications of DUS, at sites of size similar to that of LLNL, are anticipated to include:

one project engineer,

one or two geophysicists to handle ERT and temperature monitoring and data interpretation,

four certified boiler operators (one operator needed 24 hours/day).

four effluent treatment technicians/sampling technicians (one technician needed 24 hours/day),

one chemical data analyst, and

one electrician available for periodic maintenance.

- DUS consumes significant quantities of electricity, water, and, for some applications, natural gas.

These requirements can be handled via hookups to existing facilities or can be stored or generated onsite for more remote applications. 


\section{Well Close-Ups}
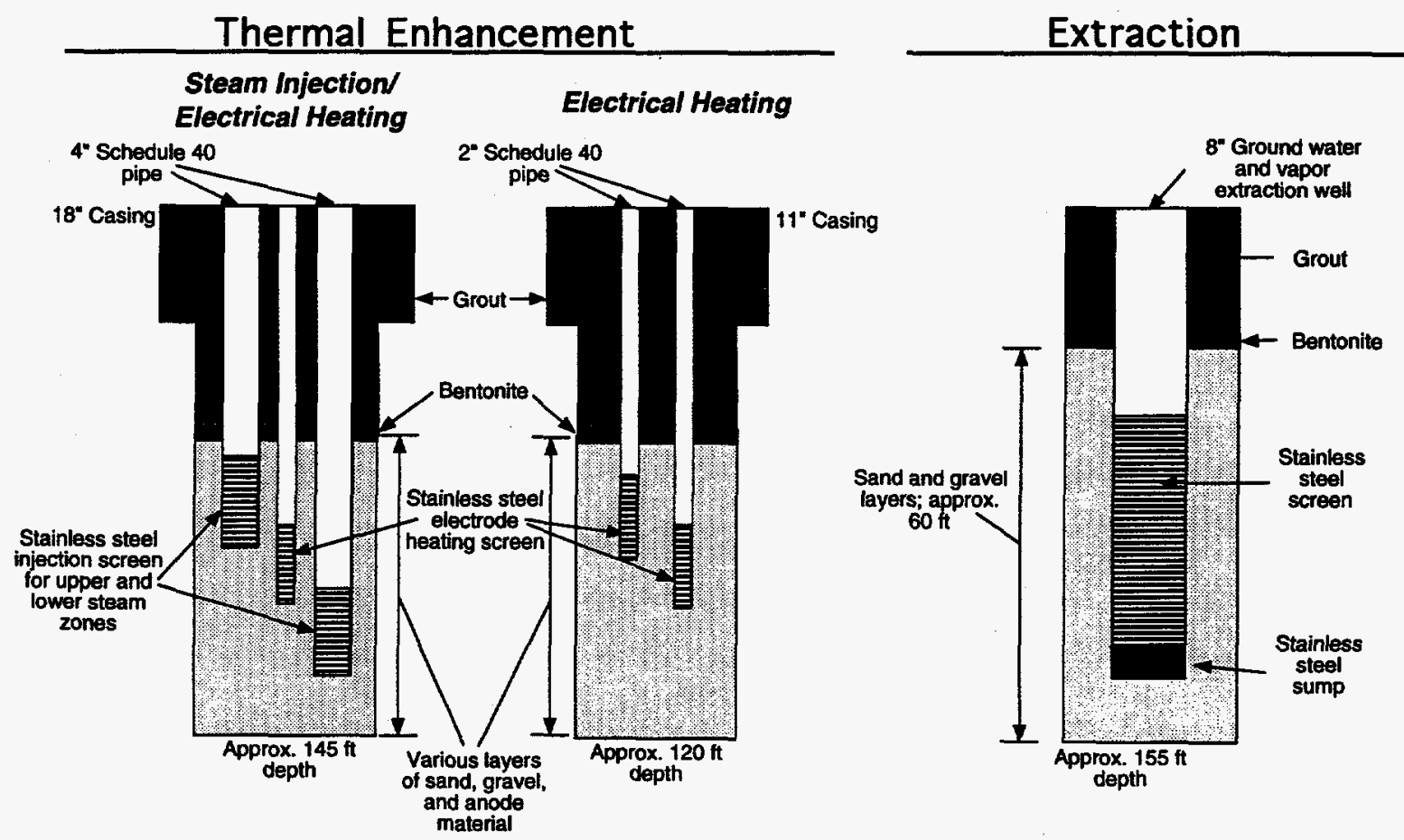

Monitoring

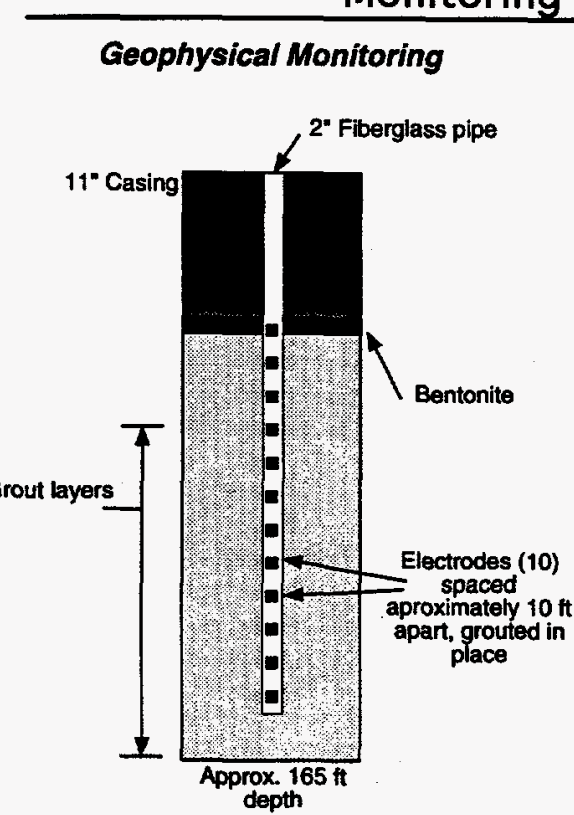

Tiltmeter

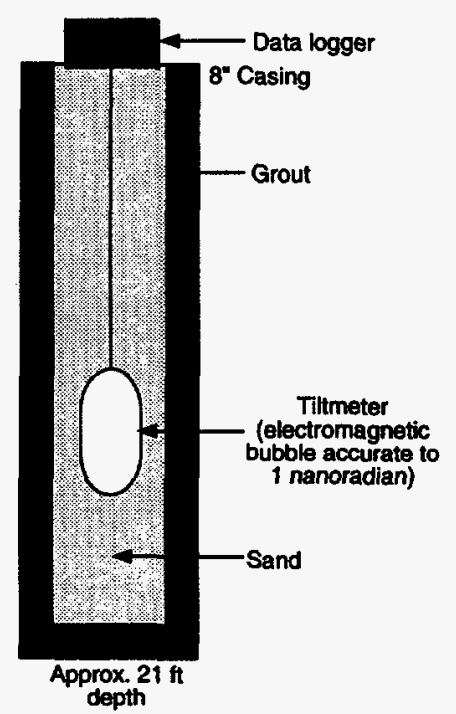

Thermocouples (not shown) are present in the monitoring, steam injection, and electric heating wells All drawings not to scale 


\section{Surface System Schematics}

\section{Steam Injection Surface}

\section{Equipment}

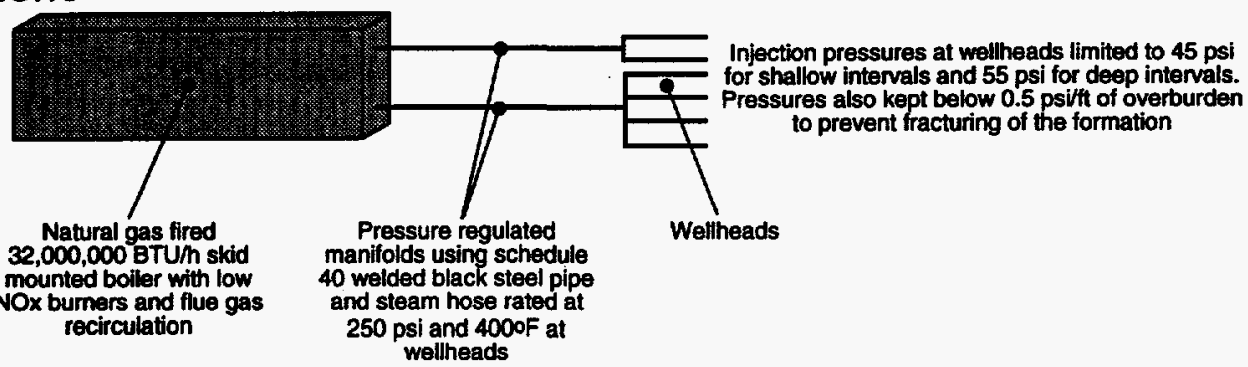

\section{Electrical Heating Surface Equipment}

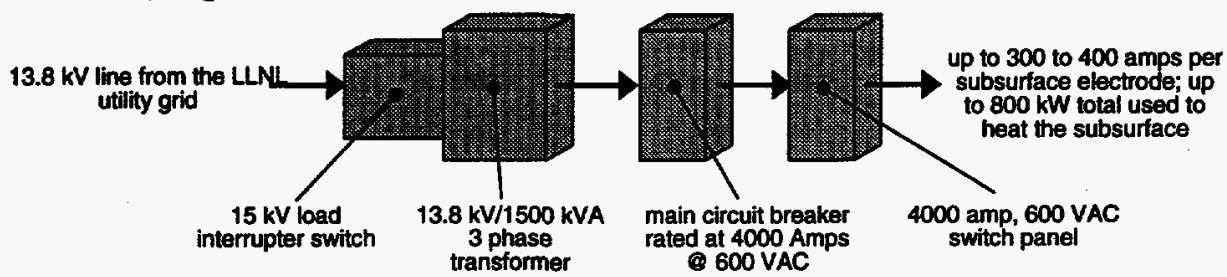

\section{Extracted Liquid and Vapor Treatment Equipment}

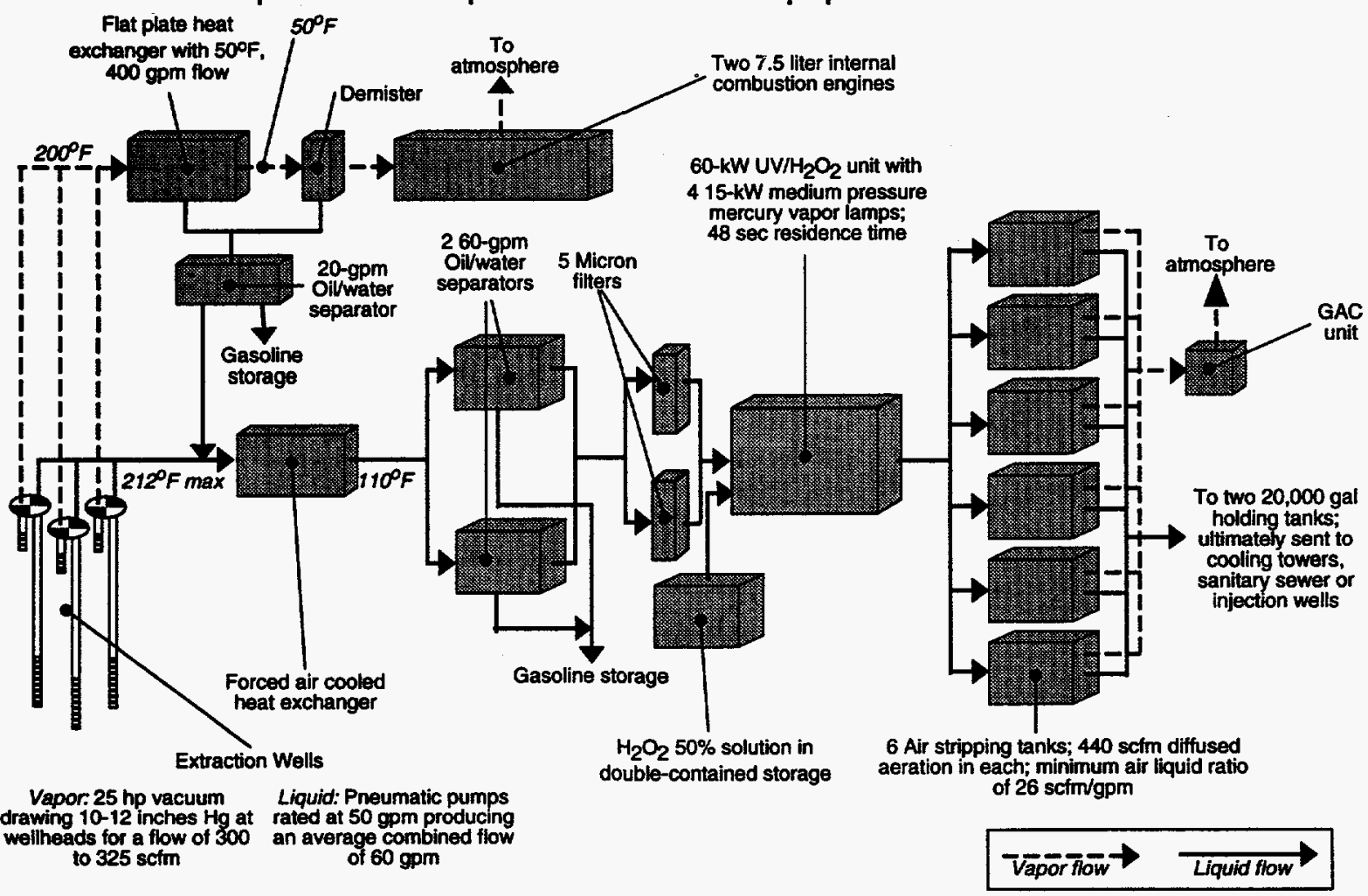

- The configuration shown above was used for the second DUS steam pass. The most significant difference from the first pass was the installation of the internal combustion engines to replace a regenerable carbon adsorption unit which could not handle the higher than anticipated vapor flow rates and hydrocarbon concentrations. 


\section{Waste Generation/Process Influents and Effluents}

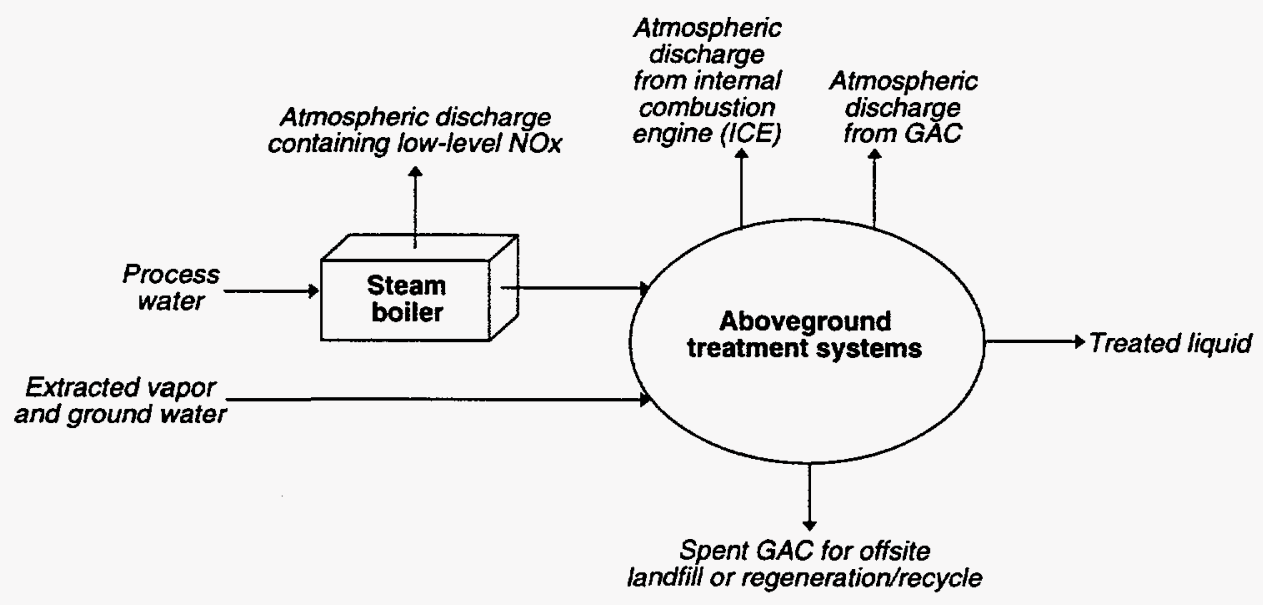




\section{PERFORMANCE DETAIL}

\section{Operational Performance}

Maintainability and Reliability - A significant percentage of the field activities
occurred in a shakedown mode where various
processes were debugged and optimized. In
addition, distinct demonstration phases used
different equipment configurations; therefore,
long-term routine maintenance and reliability
data are not available.
- Operational difficulties encountered included
biofouling (especially from microorganisms
destroyed by steaming), scaling and deposits on
sensors, clogging from fines brought to the surface,
and difficulties in maintaining the cycling, pressure
varying, high-temperature process.

Operational Simplicity
interpret monitoring data and appropriately adjust
injection and extraction flow rates. Staffing
requirements are presented on page B1.
- Routine implementation practices have not yet
been developed for all aspects of DUS. Future
development efforts will include consideration of
automating certain process monitoring activities.

\section{Schedule}

\section{Major Phases of the Demonstration Program}

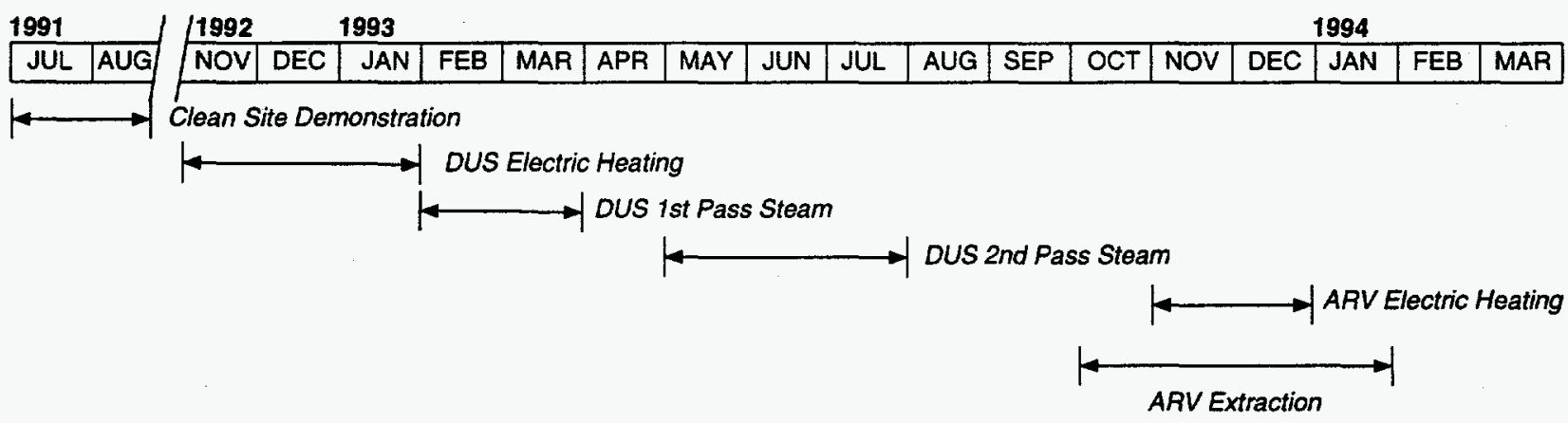

\section{Performance Validation}

- The EPA Superfund Innovative Technology Evaluation (SITE) program installed two soil borings for analysis of post-treatment conditions during the DUS demonstration. The results corroborated the data on pre- and posttreatment soil conditions developed by LLNL researchers.

- Although DUS has not been applied at any other sites, the principle of in situ thermal treatment has been demonstrated and validated through other DOE-, DOD-, and EPA-sponsored projects, which are discussed in Section 4. 


\section{Sampling, Analytical, and QAQC Issues}

\section{Sampling and Analysis Objectives}

- Obtain concentrations for calculating daily contaminant removal from vapor and liquid streams.

- Characterize the contamination removed.

- Measure destruction efficiencies of the surface treatment systems for regulatory compliance.

- Compare results with on-line monitoring instrumentation.

\section{Sampling Locations/Procedures}
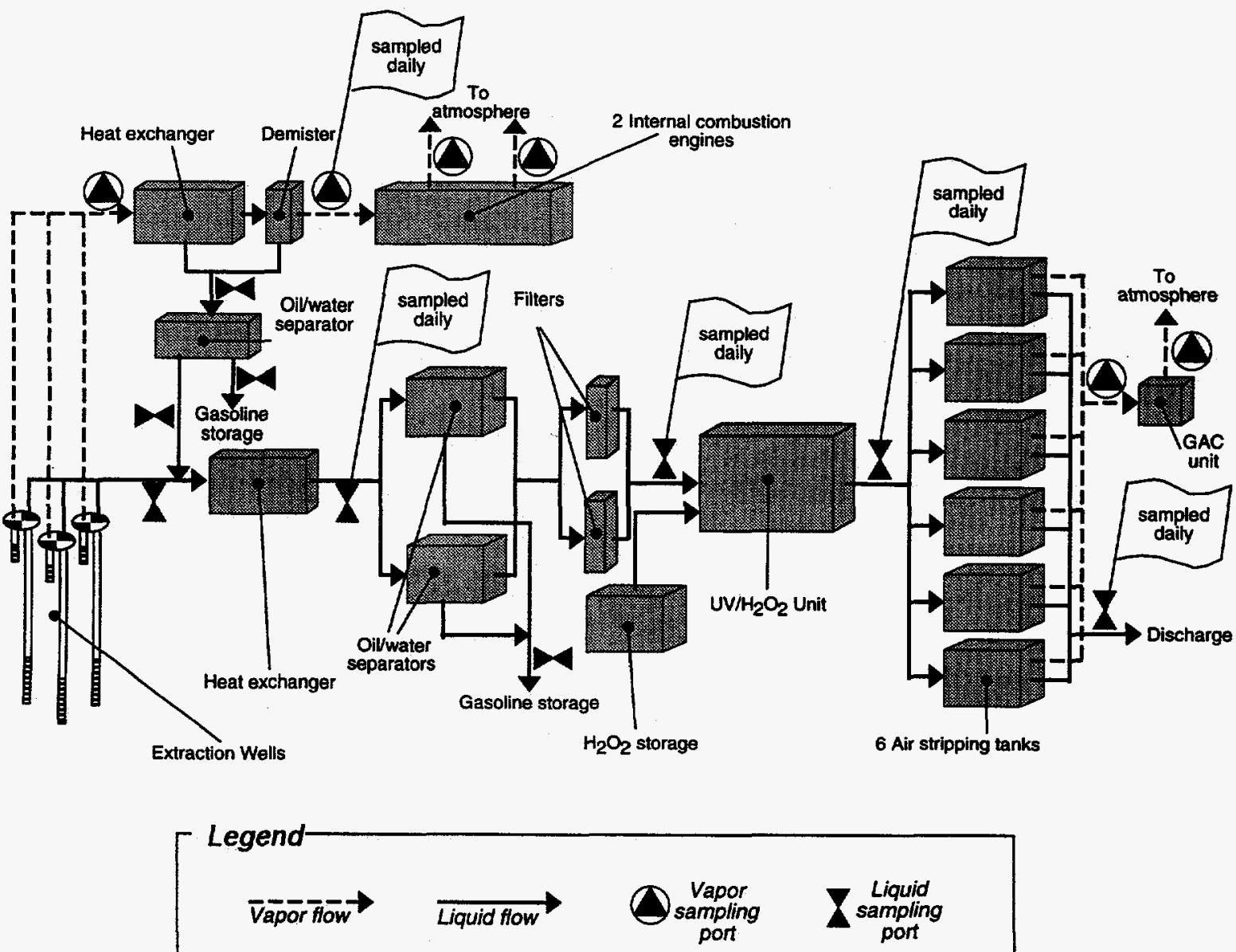

- Aqueous samples were collected in 40-ml volatile organic analysis (VOA) vials after three line volumes passed through each port unsampled.

- Free product samples were collected from the megators and placed into 40-ml VOA vials.

- All liquid phase samples were cooled to $4^{\circ} \mathrm{C}$ until analysis.

- Evacuated $500-\mathrm{ml}$ stainless steel spheres of Tedlar bags were plumbed in-line with sampling ports for collection of vapor samples. 


\section{Sampling, Analytical, and QAQC Issues (continued)}

\section{Analytical Methods}

- Aqueous samples were analyzed on-site according to EPA methods 601/602 and 8015 [total petroleum hydrocarbons (TPH)].

- Sudan IV was used as a petroleum indicator to visually determine the presence of gasoline in aqueous samples. These experiments were conducted on surplus sample volumes subsequent to gas chromatography $(G C)$ analysis

- $\mathrm{GC} /$ mass spectroscopy (GC/MS) analyses of recovered free product were performed offsite to determine composition changes with time.

- Vapor samples were analyzed on-site in accordance with EPA method T014.

- Results of onsite analyses were available within 24 hours of sampling to implement necessary changes in extraction rates and treatment facility operations.

\section{Equipment}

- TPH analyses were performed using an autosampler and purge-and-trap concentrator coupled to a Hewlett Packard (HP) 5890 Series II GC equipped with a flame ionization detector.

- EPA 601/602 and T014 analyses were performed using an HP 5890 Series $\|$ GC outfitted with an autosampler, photoionization detector, electrolytic conductivity detector, purge and trap concentrator, and low dead volume injector port.

- An HP Chemstation, an automated GC systems control and data acquisition workstation, was used to gather, process, and archive GC data.

\section{QANQC Issues}

\section{Liquid Phase}

- Quality control limits were set for surrogate recoveries, field spike recoveries, and precision and accuracy.

- The Internal Standard method was used for data calculation and reporting.

- Limits of detection were set using American Chemical Society recommendations.

- Three-point calculation checks were run daily.

- Instrument calibration was performed at least quarterly or as needed (determined by daily checks).

- Method blanks were run every 3 to 4 unknown samples. 


\section{Marketplace Opportunities}

LLNL researchers evaluated the applicability of DUS to a variety of contaminant problems in accordance with a classification methodology included in the 1994 National Research Council study of groundwater cleanup alternatives:

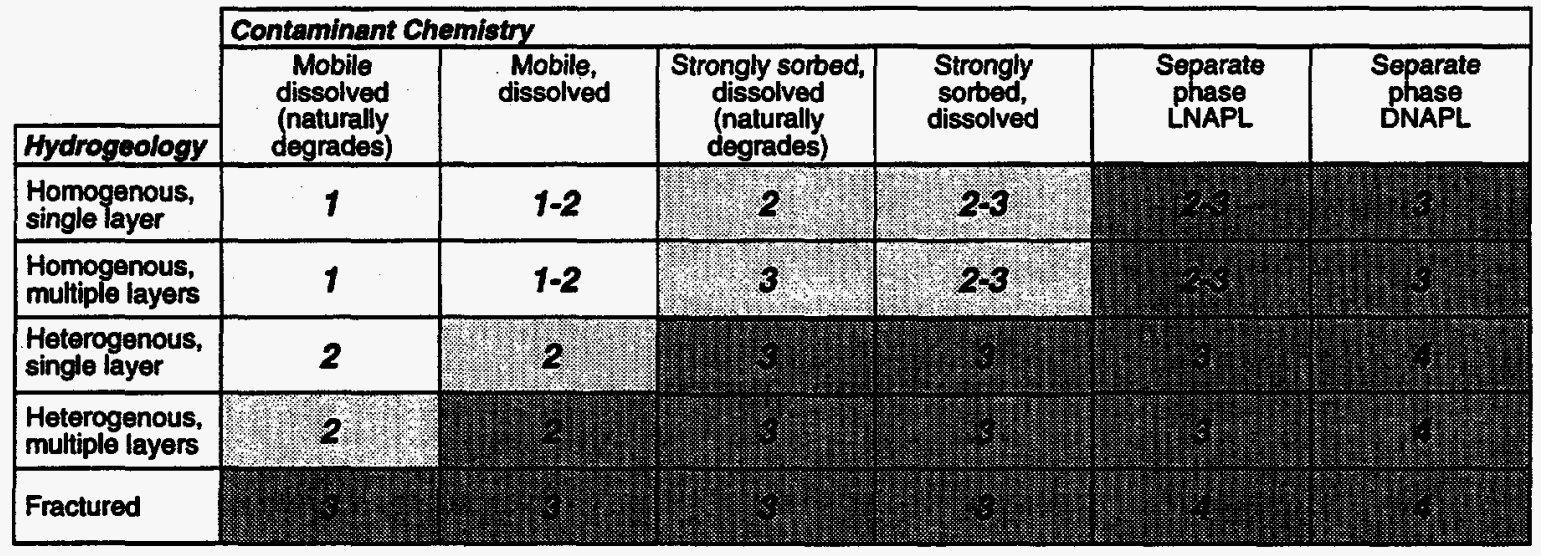

$\left[\begin{array}{ccc|}\text { Legend } & \begin{array}{l}\text { Relative difficulty of cleanup } \\ \text { (4 is most difficult) }\end{array} & \begin{array}{l}\text { Handled by biological } \\ \text { solutions }\end{array} \\ \begin{array}{l}\text { Generally handled by conventional } \\ \text { technologies (e.g., pump-and-treat } \\ \text { and soil vapor extraction) }\end{array} & \begin{array}{l}\text { Potentia/ application } \\ \text { range of DUS }\end{array} \\ \hline\end{array}\right.$

\section{Intellectual Property Rights}

\section{Primary Sponsors}

- U.S. Department of Energy, Office of Environmental Management, Office of Technology Development

\section{Collaborators}

- DUS is the product of a long-term partnership between the UC Berkeley and LLNL. Early research and development of steam heating was conducted at UC Berkeley.

- Oak Ridge National Laboratory contributed the design of a vapor process monitoring system. 


\section{Intellectual Property Rights (continued)}

\section{Existing/Pending Patents}

- Twelve patent applications have been filed for different processes and designs.

- To date, two patents have been issued:

- Patent 5,018,576 "Process for In Situ Decontamination of Subsurface Soil and Groundwater," K.S. Udell, N. Sitar, J.R. Hunt, and L.D. Stewart, assignors to The Regents of the University of California and

- Patent 5,325,918, "Optimal Joule Heating of the Subsurface," J. Berryman and W.D. Daily, assignors to the United States of America as represented by DOE.

\section{Licensing Information}

- DUS technology is commercially available through UC Berkeley/LLNL, who are currently negotiating nonexclusive licenses with several government and private parties (see Contacts section below for further information).

- LLNL has received hundreds of inquiries from site owners concerning the potential applicability of DUS to their sites. This level of interest combined with the attention focused upon other in situ thermal treatment technologies attests to the broad market for DUS. Specific commercialization activities already initiated by LLNL include:

- performing a feasibility and cost analysis to remediate a chlorinated solvent-contaminated site at the DOE Pinellas facility,

- the design of a system to remediate shallow underground hydrocarbons at a U.S. Navy facility in California,

- the conceptual design to remediate a large shallow fuel-contaminated U.S. Army Corps of Engineer managed site in Alaska, and

- other private sector projects.

These efforts are part of LLNL. efforts to transfer DUS know-how to new licensees of the technology. 


\section{APPENDIX E}

\section{COST DETAIL}

\section{Demonstration Costs}

- DUS costs were obtained from a variety of sources at LLNL. The costs of demonstration were based upon overall funding received from DOE, program management planning documents, capital costs for individual equipment components, and actual operating costs incurred during the second steam pass (which is most representative of operating costs for future applications).

- LLNL has prepared an estimate of potential cost savings if DUS were applied at the same site in the future with the benefit of lessons learned and without research-oriented activities. Resultant total savings would be approximately $\$ 4,000,000$ or a $40 \%$ reduction versus demonstration costs.

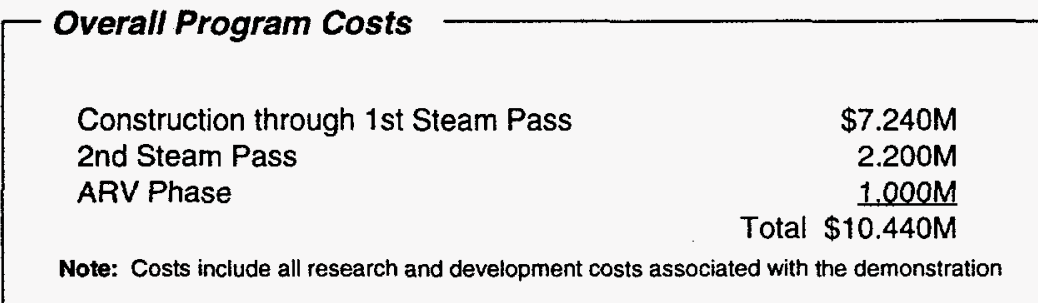

Identified Cost Components

The following program elements were taken from planning documents.

\section{Project Management}

Management

Analysis and report writing

Safety plan writing and review

Permitting

Equipment design
$\$ 225,000$

335,000

70,000

65,000

$\underline{200,000}$

$\$ 895,000$

Process Monitoring

Design

ERT and thermal

Tiltmeter

Hydraulic testing
Characterization and Compliance Monitoring

Drilling-phase sampling

$\$ 315,000$

Pre-electrical heating sampling $\quad 35,000$

Pre-steam sampling $\quad 20,000$

Post-steam sampling (4 new wells) $\quad 50,000$

Compliance monitoring $\quad 10,000$

Sampling during experiment $\quad 25,000$

$\$ 455,000$

$\$ 50,000$

270,000

70,000

$\underline{55.000}$

$\$ 445,000$ 


\section{Demonstration Costs (continued)}

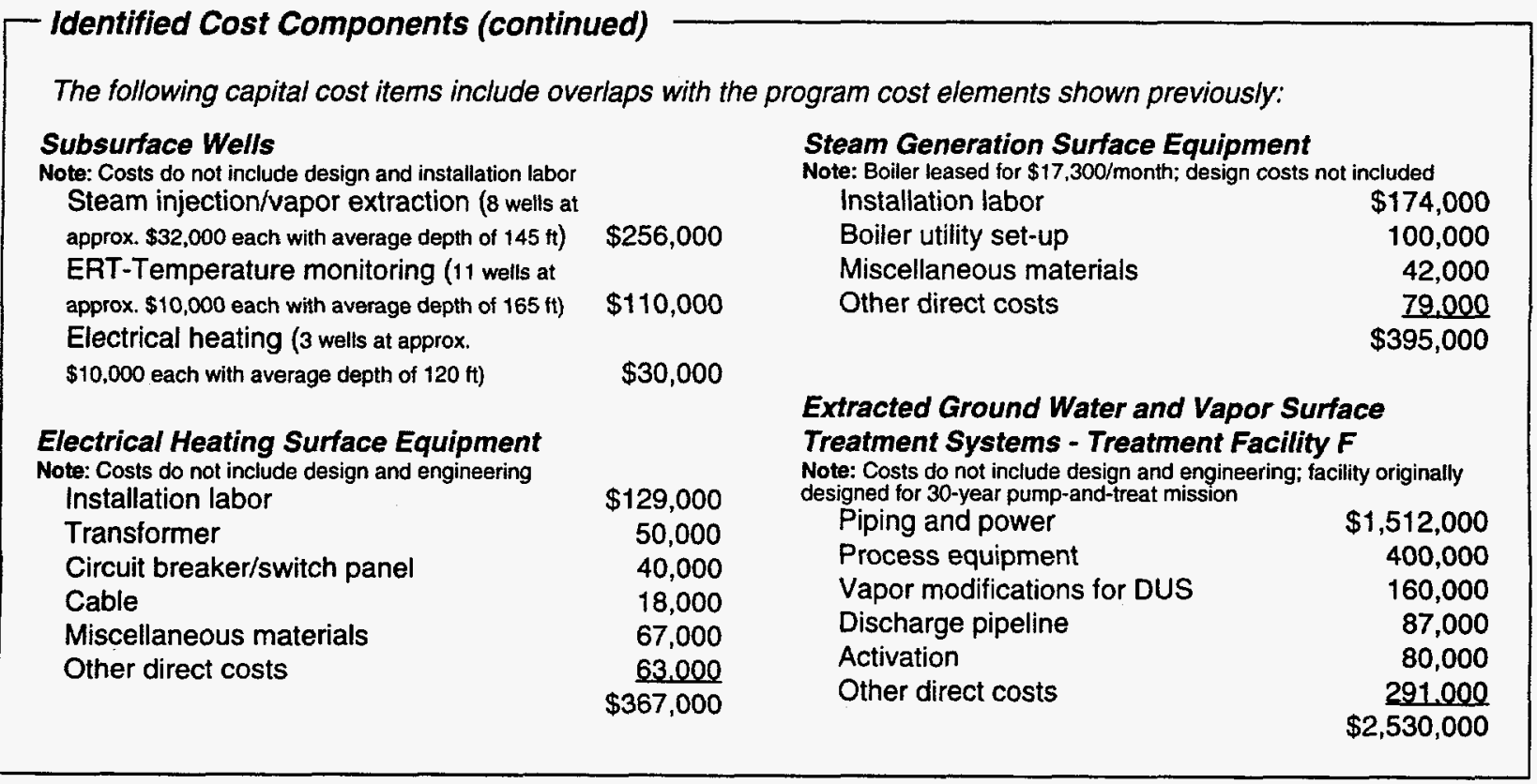

\section{Operating Costs}

\section{Utility Consumption}

Boiler natural gas $\left(3.8 \mathrm{E} 10 \mathrm{tt}^{3} @ \$ 0.39 / 100,000 \mathrm{t}^{3}\right)$

Boiler water (3.6E6 gal $\left.\$ 1.25 / 100 \mathrm{ft}^{3}\right)$

Boiler electricity $(40,000 \mathrm{kWh} \$ 0.06 / \mathrm{kWh})$

Electricity for electrical heating $(200,000 \mathrm{kWh} @ \$ 0.06 / \mathrm{kWh})$

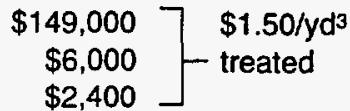

$\$ 12,000$

Labor and Material Costs for 2nd Steam Pass (all values in thousands of dollars) Note: Costs represent 6 weeks of 24-hr operations and continuously monitored experimental conditions

\begin{tabular}{|c|c|c|c|c|c|}
\hline & $\begin{array}{c}\text { Scientists and } \\
\text { Engineers }\end{array}$ & Technicians & $\begin{array}{l}\text { External } \\
\text { Analysis }\end{array}$ & Materials & TOTALS \\
\hline Phase 1: Planning & 44 & - & - & - & 44 \\
\hline Phase 2: Maintenance and Modification & 2 & 31 & - & 27 & 60 \\
\hline Phase 3: Operations & & & & & \\
\hline Steam Injection Operations & & & & & \\
\hline Periods of steam injection & 27 & 51 & - & 167 & 245 \\
\hline Periods of no steam injection & 14 & 5 & - & - & 19 \\
\hline ERT Monitoring & 13 & 22 & - & - & 35 \\
\hline Additional UC Berkeley support & - & 50 & - & - & 50 \\
\hline Effluent Treatment Operations & & & & & \\
\hline Effluent treatment & 35 & 203 & - & 91 & 329 \\
\hline Sampling and analysis & 50 & 17 & 18 & - & 85 \\
\hline Phase 4: Post Steaming Characterization & & & & & \\
\hline Sampling & 41 & 36 & - & - & 77 \\
\hline Soil Analysis & - & - & 83 & - & 83 \\
\hline Drill Rig & - & 26 & - & 9 & 35 \\
\hline $\begin{array}{l}\text { Phase 5: Reporting and Technology Transfer } \\
\text { Phase 6: Dismantling (conservative estimate) } \\
\text { Contingencies }\end{array}$ & 400 & - & - & - & $\begin{array}{l}400 \\
181 \\
228\end{array}$ \\
\hline
\end{tabular}


Cost Considerations for Future Applications

Cost Savings for Commercial Applications

- LLNL has prepared an estimate of potential cost savings if DUS were applied at the same site in the future with the benefit of lessons learned and without research-oriented activities. The estimated savings would be derived from:

- reduction in design effort by over $50 \%(-\$ 206 \mathrm{~K})$

- elimination of discharge lines \& transformer

- elimination of modification designs for $2 n d$ pass modifications ( $\$ 855 \mathrm{~K})$

- use of temporary steam generation equipment $(-\$ 355 \mathrm{~K})$

- reduced site characterization (-\$210K)

- replacement of UV unit with air stripper (-\$500K) steam and ARV phases $(-\$ 604 \mathrm{~K})$

- reduced management effort (-\$100K)

- reduced science \& engineering staff requirements $(-\$ 166 \mathrm{~K})$

- reduced operations staff requirements $(-\$ 505 \mathrm{~K})$

- reduced reporting and safety documentation preparation $(-\$ 470 \mathrm{~K})$

Resultant total savings would be approximately $\$ 4,000,000$ or a $40 \%$ reduction versus demonstration costs

\section{Cost Estimates Completed for Additional Applications}

- LLNL researchers prepared a cost estimate for applying DUS to a shallow chlorinated solvent spill at the DOE Pinellas facility. Key results of that cost estimate were:

- average cleanup costs of approximately $\$ 65 / \mathrm{cu} . y d .$, which was based upon a fixed cost of approximately $\$ 1.5 \mathrm{M}$ and a variable cost of $\$ 20 / \mathrm{cu}$.yd., indicated the increased cost-effectiveness of the technology at larger sites

- a total cost for DUS implementation was estimated as less than the first year cost of constructing and operating a conventional groundwater pump-and-treat facility 


\section{APPENDIX F}

\section{REFERENCES}

\section{Major References for Each Section}

Demonstration Site Characteristics:

Technology Description:

Performance:

Cost:

Regulatory/Policy Issues:

Lessons Learned:

Commercialization:

\author{
Sources (from list below) 1 and 17 \\ Sources $1,4,6,7,8,9,10,11$, and 20 \\ Sources $1,2,4,6,7,8,9,10,11,13,14,15,18$, and 20 \\ Sources 1,3 , and 19 \\ Sources $1,6,8,9,14$, and 15 \\ Sources $1,2,6,7,8,9,10,11,13,14,15$, and 18 \\ Sources $1,5,8,12$, and 16
}

\section{Chronological List of References and Additional Sources}

1. Personal communications with Roger Aines, Lawrence Livermore National Laboratory, (510) 423-7184, November 1994-January 1995.

2. Personal communications with Marina Jovanovich, Lawrence Livermore National Laboratory, (510) $422-2144$, January 1995.

3. Memorandum from Roger Aines, LLNL to Jesse Yow, LLNL, "Summary of Dynamic Underground Stripping Funding," December 19, 1994.

4. Personal communications with Robin Newmark, LLNL, (510) 423-3644, November 1994.

5. U.S. Environmental Protection Agency, Superfund Innovative Technology Evaluation Program: Technology Profiles Seventh Edition, EPA/540/R-94/526, November 1994.

6. Design, Construction and Operation of the Dynamic Underground Stripping Facility at Lawrence Livermore National Laboratory, draft, Lawrence Livermore National Laboratory, Livermore, CA, 1994.

7. Roger Aines, William Siegel, and Everett Sorenson, Gasoline Removal During Dynamic Underground Stripping: Mass Balance Calculations and Issues, draft, Lawrence Livermore National Laboratory, Livermore, CA, 1994.

8. Roger Aines, Robin Newmark, John Ziagos, Alan Copeland, and Kent Udell, Cleaning Up Underground Contaminants: Summary of the Dynamic Underground Stripping Demonstration, LLNL Gasoline Spill Site, Lawrence Livermore National Laboratory, Livermore, CA, UCRL-ID-118187, September 1994.

9. William H. Siegel and Everett Sorenson, Treatment Facility $F$, internal document, Lawrence Livermore National Laboratory, Livermore, CA, 1994.

10. Jesse L. Yow, Roger D. Aines, Robin L. Newmark, Kent S. Udell, and John P. Ziagos, Dynamic Underground Stripping: In Situ Steam Sweeping and Electrical Heating to Remediate a Deep Hydrocarbon Spill, draft, Lawrence Livermore National Laboratory, Livermore, CA, 1994.

11. Robin L. Newmark, and the DUS Project Gasoline Spill Site Monitoring Team, Using Geophysical Techniques to Control in Situ Thermal Remediation, draft, Lawrence Livermore National Laboratory, Livermore, CA, 1994.

12. J.A. MacDonald, and M.C. Kavanaugh, "Restoring Contaminated Groundwater: An Achievable Goal?", Environmental Science \& Technology, Vol. 28, No. 8, August 1994. 


\section{Chronological List of References and Additional Sources (continued)}

13. Marina C. Jovanovich, Roger E. Martinelly, Michael J. Dibley, and Kenneth L. Carroll, Process Monitoring of Organics, revised draft, Lawrence Livermore National Laboratory, Livermore, CA, August 1994.

14. Jerry J. Sweeney, and Alan B. Copeland [eds.], Treatment Facility F, Accelerated Removal and Validation Project, draft, Lawrence Livermore National Laboratory, Livermore, CA, April 1994.

15. Demonstration of Dynamic Underground Stripping at the LLNL Gasoline Spill Site: Summary of Results 3/94, draft, Lawrence Livermore National Laboratory, Livermore, CA, March 1994.

16. U.S. Department of Energy, Office of Environmental Management, Office of Technology Development, Technology Catalogue, First Edition, February 1994.

17. D.J. Bishop [ed.], Dynamic Underground Stripping Characterization Report, draft, Lawrence Livermore National Laboratory, Livermore, CA, January 1994.

18. Mike Brown, Roger Liddle, Alan Copeland, and John Ziagos, "Headquarters Dynamic Underground Stripping Briefing," presentation materials, October 1993.

19. John Bremser and Steven Booth, 1995, Cost Effectiveness of Thermal Enhanced In Situ Soil Remediation Technologies, draft report, Los Alamos National Laboratory, Los Alamos, NM, April 1995.

20. A. Ramirez, W. Daily, D. LaBrecque, E. Owen, and D. Chesnut, "Monitoring an Underground Steam Injection Process Using Electrical Resistance Tomography, " Water Resources Research, v. 29, No.1, 1993. 
This summary was prepared by:

\section{CKY incorporated Environmental Services}

140 E. Division Rd. Suite $\mathrm{C}-3$

Oak Ridge, Tennessee, 37830

Contact: Kenneth Shepard (615) 483-4376

in conjunction with:

Stone \& Webster Environmental

Technology \& Services

245 Summer Stree

Boston, MA 02210

Contact: Bruno Brodfeld (617) 589-2767

Assistance was provided by the

LAWRENCE LIVERMORE NATIONAL LABORATORY

ENVIRONMENTAL TECHNOLOGY PROGRAM

EARTH SCIENCES DIVISION

which supplied key information and reviewed report drafts.

Final editing and production was provided by the

Colorado Center for Environmental Management

999 18th Street Suite 2750

Denver CO 80202

(303) 297-0180

for:

HAZARDOUS WASTE REMEDIAL ACTIONS PROGRAM

Environmental Managment and Enrichment Facilities

Oak Ridge, Tennessee 37831-7606

managed by

MARTIN MARIETTA ENERGY SYSTEMS

for the

U.S. Department of Energy

under Contract DE-AC05-84OR-21400

950R-7400-001-008 